MŰHELYTANULMÁNYOK

DISCUSSION PAPERS

MT-DP - 2006/9

\title{
Nominal growth of a small open economy
}

\author{
PETER BENCZUR - ISTVAN KONYA
}




\section{Discussion papers \\ MT-DP - 2006/9}

Institute of Economics, Hungarian Academy of Sciences

KTI/IE Discussion Papers are circulated to promote discussion and provoke comments. Any references to discussion papers should clearly state that the paper is preliminary. Materials published in this series may be subject to further publication.

Nominal growth of a small open economy

Peter Benczur,

Corresponding author,

Magyar Nemzeti Bank and Central European University

benczurp@mnb.hu

Istvan Konya,

Magyar Nemzeti Bank and Central European University;

konya@mnb.hu

ISBN $963 \quad 9588 \quad 80 \quad 6$
ISSN $1785-377 X$

Publisher:

Institute of Economics, Hungarian Academy of Sciences 


\title{
Nominális növekedés egy kis nyitott gazdaságban
}

\author{
Benczúr Péter - Kónya István
}

\section{Összefoglaló}

Tanulmányunkban egy rugalmas árazású, kétszektoros nominális növekedési modellt építünk föl, amit a felzárkózás (tőkefelhalmozás) nominális aspektusainak a tanulmányozására használunk. Egy klasszikus kis nyitott gazdaságot tekintünk, a külfölddel versenyző és nem versenyző szektorokkal, amit a beruházások fokozatosságával és a pénz szerepével bővítünk. Utóbbi feltevésünket az motiválja, hogy a kevésbé fejlett OECD országokban (különösen az új EU tagoknál) a háztartások pénzügyi megtakarításaikat jórészt bankbetétben tartják. A modellkeret a következő eredményeket adja: (1) a monetáris rezsim rugalmassága (miszerint a pénzmennyiség és/vagy az árfolyam teljesen flexibilis-e) számít; (2) nem tökéletes rugalmasság esetén (mint például egy valutatanács) a nominális árfolyam szintje középtávon befolyásol reálváltozókat is, de hosszútávon csak a nominálváltozókat; (3) a reálegyensúlyi pálya mentén (ami implementálható például flexibilis árfolyamrendszerrel) a tőkefelhalmozás a reálárfolyam (relatív ár) felértékelődését okozza; (4) flexibilis árfolyamrendszer esetén ez nominális felértékelődéssel is jár.

\section{Tárgyszavak:}

kétszektoros növekedési modell, háztartások pénzügyi megtakarításai, Tobin-q elmélet, nominálsokkok reálhatásai, egyensúlyi reálárfolyam. 


\title{
Nominal growth of a small open economy*
}

\author{
Peter Benczur ${ }^{\dagger}$ and Istvan Konya ${ }^{\ddagger}$
}

August 2006

\begin{abstract}
This paper develops a flexible price, two-sector nominal growth model, in order to study the nominal aspects of capital accumulation (convergence). We adopt a classical model of a small open economy with traded and nontraded goods, and enrich its structure with gradual investment and a preference for real money holdings. This latter is motivated by the fact that a large fraction of less developed OECD country (in particular: new EU members) households' assets are local currency bank deposits. The modelling framework gives the following results: (1) the fexibility of the monetary regime (whether money or the exchange rate is allowed to fluctuate freely) matters; (2) under imperfect fbating (like in a currency board), the level of the exchange rate has a medium-run impact on nominal and real variables but no long-run real effect; (3) along the real equilibrium path (which can be implemented by fexible exchange rates), capital accumulation implies an increase in the price of nontradables (a real appreciation); (4) under fexible exchange rates, capital accumulation also implies a nominal appreciation.
\end{abstract}

JEL Classification Numbers: F32, F41, F43

Keywords: two-sector growth model, household portfolios, q-theory, real effects of nominal shocks, equilibrium real exchange rates.

\section{Introduction}

The nominal exchange rate is one of the most important prices for a small open economy, influencing its structure and performance in the short-run. There are strong linkages among permanent or temporary exchange rate movements, the external position, the growth rate and fluctuations of the economy, the latter often showing sectoral asymmetries as well.

\footnotetext{
${ }^{*}$ We are grateful to Andrew Blake, Ágnes Csermely, Michal Kejak, Miklós Koren and participants of the conference celebrating the 50th anniversary of IE-HAS, a seminar at MNB, the 4th Workshop on Macroeconomic Research and the IE-HAS Summer Workshop for comments and suggestions. All the remaining errors are ours.

${ }^{\dagger}$ Magyar Nemzeti Bank and Central European University. Corresponding author, email: benczurp@mnb.hu

${ }^{\ddagger}$ Magyar Nemzeti Bank and Central European University; email: konya@mnb.hu
} 
The nominal exchange rate can also influence the intertemporal behavior of a small open economy. As suggested by consumption smoothing, converging economies should be borrowing against their future income, while they also build up their asset holdings. Indeed, a salient feature of new EU member states is that their households accumulate both assets and liabilities. ${ }^{1}$ Compared to industrial economies, as we will document, a large fraction of these assets are local currency bank deposits and bonds, the value of which moves together one in one with nominal exchange rate movements. This implies that the evolution of the nominal exchange rate will influence this process. Moreover, whether exchange rates are fexible, fixed or "frozen" (like in a currency board arrangement) also determines how much nominal asset accumulation can be achieved by nominal appreciation and how much requires household savings from labor income. Such a link then has repercussions for capital accumulation, growth and sectoral (tradables versus nontradables) reallocations. Our objective is to develop a simple but suffi ciently rich framework, which is capable of addressing the aggregate and sectoral features of such a nominal convergence.

The structure of the model is the following. We consider a small open economy, with a traded and a nontraded sector. Both sectors use labor and capital, but not necessarily with the same intensity. Factors are perfectly mobile between the two sectors, but their international mobility is restricted. In particular, labor is immobile between countries, while international capital fbws are hampered by adjustment costs. We adopt the now classic Tobin-q approach to capture gradual capital fbws.

The source of growth is capital accumulation. ${ }^{2}$ We assume that the initial capital stock is below the steady state level, so the country experiences capital accumulation and excess growth along its convergence path. For simplicity, we assume that the entire capital stock is owned by foreigners.

The nominal side of the growth process is represented by the well-known "money-in-theutility" framework, which assumes that households derive utility directly from holding (real) money balances. Apart from being a technical assumption, this is motivated by the observation that a large share of new EU member country household assets are held in local currency bank deposits and bonds (see section 2.2 for more details). ${ }^{3}$ Thus we interpret money-in-the-utility

\footnotetext{
${ }^{1}$ This is likely to be true for other emerging economies as well. Unfortunately, the lack of detailed financial balance sheet data for non EU or OECD countries prevents us from making such a statement.

${ }^{2}$ One could extend the model to allow for exogenous TFP growth, either symmetric or asymmetric across sectors. In the case of an exogenous TFP growth in tradables, almost all of our results remain identical in terms of effective (normalized) variables, but the expressions and derivations are substantially more complicated. For this reason, we stick to the case of constant TFP.

${ }^{3}$ An alternative would be to consider a cash-in-advance economy, which assumes that certain transactions require the appropriate cash at hand. Both assumptions are largely ad hoc and lead to similar conclusions (under the simplest parametrization, the cash-in-advance economy features shock responses that are larger on impact but less persistent). In our case, however, money-in-the-utility has the extra ability to represent an asset
} 
as an asset accumulation motif. As the income of consumers grows, they want to consume more and also to hold more money. By having access to an international bond market, they can borrow against their future income, thus being able to consume more and hold more money. To prevent complete consumption smoothing, we utilize the standard assumption that there is an endogenous risk premium (one that is decreasing in the countrys average net asset holdings). Together with gradual investment, these intertemporal elements are already suffi cient to produce a lasting effect of one-period nominal shocks.

Fixed income instruments (like cash, bank deposits and bonds) are inherently sticky with respect to nominal exchange rate movements, their value in foreign currency changes one-toone. In this sense, their presence can be viewed as an "original stickiness". By neglecting price and wage setting frictions, we want to show that nominal exchange rates can have systematic medium-run real effects even under fexible prices and wages. ${ }^{4}$ Another consideration is the simplicity of the modelling framework.

After setting up the model we turn to the analysis of the nominal growth process. We first show that in case of fexible exchange rates, the nominal economy behaves identically to the real economy: capital accumulation increases labor income, leading to a gradual increase in money holding, which is implemented by an appreciating nominal exchange rate. This is a formal version of the popular phrase that FDI infbws put an appreciating pressure on nominal exchange rates. Equivalently, even with exchange rates fixed, the right amount of money creation by the central bank can implement the real path.

The nominal and the real paths differ, however, when both the exchange rate is fixed and money growth is exogenous. This is the case, for example, when the country operates a currency board economy (zero money growth), or chooses the euro conversion rate (joining a monetary union). Historically, the gold standard shared the same features. Under these assumptions any increase in the domestic money stock must come from abroad. This necessitates either a trade surplus or foreign borrowing. Since borrowing is costly (debtors face a positive risk premium), the nominal economy features an extra saving motif, the accumulation of nominal wealth. Consequently, the growth path differs from that of an economy where money plays no role.

We also compare two nominal (currency board) paths which differ only in the level of the exchange rate. Different nominal exchange rates lead to relatively small but highly persistent deviations: from identical capital stocks, foreign bond and local currency holdings, a stronger

accumulation motif. Moreover, we also want to relate our results to current neokeynesian models, which usually employ money-in-the-utility.

${ }^{4}$ Tille (2005) is another example when exchange rate movements can lead to persistent real effects without pricing or wage setting frictions. 
nominal exchange rate means a higher euro value of local currency holdings. As tradable prices are fixed in euros, this is indeed a positive wealth shock.

The clearest case for such a comparison is when a country decides over its entry rate into a monetary union; but a realignment of a fixed exchange rate also shares these features as long as money supply is not completely fexible. An important application of our model is thus the choice of the euro conversion rate for EMU aspirants. As the role of money and bank deposits is larger in these economies than in previous EMU entrants, we can expect a stronger real impact of this choice. The historical episode of converting the East German currency into Dmarks also highlights the importance of the wealth effect of currency conversion and its persistent real effects; but one could also look back at the restoration of the gold standard in the UK after WWI.

We believe that around a currency changeover, such a wealth effect is a more important source of real effects than pricing rigidities: firms can always use the need to post prices in the new currency as an occasion to reoptimize their prices. Hobijn, Ravenna and Tambalotti (2006) documents that this was clearly the case in the restaurant sector of the euro area in January 2002 .

The paper is organized as follows. The next section puts the model into context. Section 3 describes the model. Section 4 explains the mechanics and the main results for the fexible exchange rate case, while Section 5 discusses the currency board regime. Section 6 offers some quantitative policy simulations, and Section 7 concludes. The Appendix contains an illustrative episode of the symptoms of excessive household wealth and all the detailed calculations.

\section{The context of the model}

\subsection{Theory}

Usual explanations for nominal shocks having lasting real effects usually build on staggered price or wage contracts. An early example is Taylor (1980). Recently, state- or time-dependent pricing models constitute as the workhorse for analyzing nominal scenarios (see chapter 3 of Woodford (2003) for a general discussion). Instead of pricing problems, we focus on nominal wealth accumulation (captured by money-in-the-utility), which is also influenced by nominal shocks.

The major building blocks of our model are money-in-the-utility (a nominal effect), a debtdependent interest rate, gradual investment (a real friction) and sectoral technology differences (capital-labor intensities). These are already suffi cient to produce real effects of a nominal 
shock. ${ }^{5}$ There is also a positive correlation between domestic savings and investment (like the Feldstein-Horioka (1980) puzzle), although investment is not financed from domestic savings at all. The link comes from a "crowding out" effect of nominal expenditures on investment, which is due to the general equilibrium development of relative prices.

Technically speaking, the nominal effect comes from the gradual adjustment of nominal expenditures to money (nominal asset holdings). This can be also viewed as some sort of a nominal rigidity (illusion), which ensures that nominal shocks have an impact effect on spending. ${ }^{6}$ As we will document, new EU member state households view money, bank deposits and local bonds as a major vehicle of financial wealth. As the economy grows, consumers want to increase these asset holdings. The fact that the assets are nominal (local currency) gives the notion of nominal convergence. Moreover, nominal shocks can revalue this stock (as argued by Lane and Milesi-Ferretti (2004), or Gourinchas and Rey (2004)), which in turn changes consumer behavior. Tille (2005) also analyzes the real effects of such a revaluation. In our case, this revaluation happens automatically as the price of tradable goods is fixed in foreign currency.

It is well-known that having access to an international bond market where the world-wide interest rate is constant (and equal to the domestic discount rate) would lead to complete consumption smoothing, implying unrealistic levels of foreign indebtedness. Moreover, such open economy models could not pin down the steady state level of foreign debt. Schmitt-Grohe and Uribe (2003) offer various ways of closing such open economy models, one being a debtdependent interest rate. That assumption uniquely determines the level of debt in steady state, and also slows down consumption smoothing.

The presence of a traded and a nontraded sector allows us to merge trade theory insights with a monetary framework: for example, the presence of nontraded goods means that a redistribution of income between countries will affect their relative wages (the classical transfer problem, like in Krugman (1987)), or the Stolper-Samuelson theorem, linking changes in goods prices with movements in factor rewards.

Many current papers point to the importance of gradual investment in shaping business cycle properties, inflation or real exchange rate behavior. Eichenbaum and Fisher (2004) argue that the empirical fit of a Calvo-style sticky price model substantially improves with firm-specific capital (and a nonconstant demand elasticity). Christiano et al (2001) present a model in which

\footnotetext{
${ }^{5}$ Benigno (2003) and part 3.2.5 of Woodford (2003) also highlight the role of sectoral asymmetries, though not in the context of traded versus nontraded goods.

${ }^{6}$ Classical real exchange rate (trade theory) models often use the relationship $E=V H$, nominal expenditures being proportional to money holdings, to allow for nominal shocks. Examples include part 3 of Dornbusch (1980) and Krugman (1987). Dornbusch and Mussa (1975) show that under certain conditions (power-Cobb-Douglas utility and constant inflation), the intertemporal optimization problem with money-in-the-utility implies a saddle path with $E=V H$.
} 
moderate amounts of nominal rigidities are suffi cient to account for observed output and inflation persistence, after introducing variable capital utilization, habit formation and capital adjustment costs. Chapter 4 of the Obstfeld and Rogoff (1996) textbook contains an exposition of a twosector growth model (the standard Balassa-Samuelson framework), with gradual investment in some of the sectors. We depart from these approaches by dropping staggered price setting, but - unlike Obstfeld and Rogoff -still allowing for a nominal side of the economy.

Huffman and Wynne (1999) develop a multisector real model with investment frictions (sector-specific investment goods and costs of adjusting the product mix in the investment sector). Their objective is, however, to match the closed economy comovements of real activity across sectors (consumption and investment). In our model, the two sectors have a completely different nature (traded and nontraded). These two sectors do not necessarily move together, as indicated by the countercyclicality or acyclicality of net exports (see Fiorito and Kollintzas (1994) for G7 countries, Aguiar and Gopinath (2004) for emerging economies). Aguiar and Gopinath (2004) also construct a one-sector real model to explain the countercyclicality of net exports and the excess volatility of consumption. Balsam and Eckstein (2001) develop a real model with traded and nontraded goods, aimed at explaining the procyclicality of Israels net exports and excess consumption volatility.

The growth literature also employs multisector models, but the two sectors there differ in the investment good they produce (physical versus human capital). Examples include Rebelo (1991) and Lucas (1988). Ventura (1997) is an example of a multisector growth model with an explicit trade framework. His model of growth in interdependent economies clearly illustrates the importance of merging trade and growth theory. The implications of a nontraded sector, however, are not addressed by that paper. None of the existing models, up to our knowledge, share all the distinctive features of our model: a fexible price, nominal, open-economy, twosector model with investment frictions, giving a lasting real effect of nominal disturbances. ${ }^{7}$

\subsection{Stylized facts}

Let us start by documenting the specifics of EU and OECD household financial balance sheets. Figure 1 plots the three-year average household asset per GDP position for 27 countries, for years $2002-04 .^{8}$ It is immediate from the graph that new member and candidate states exhibit much lower asset holdings. This is somewhat less true for previous catching-up countries like

\footnotetext{
${ }^{7}$ In fact, the general equilibrium tax incidence analysis of Harberger (1962) has very similar features: in his analysis, taxation plays a related role to the nominal exchange rate in our model.

${ }^{8}$ The countries are: Australia, Canada, Japan, Korea and the US; Austria, Belgium, Denmark, Finland, France, Germany, Italy, the Netherlands, Norway, Portugal, Spain, Sweden and the UK; Bulgaria, the Czech Republic, Estonia, Hungary, Latvia, Lithuania, Poland, Romania (data exists only for 1999), Slovakia and Slovenia. Data are from the Eurostat and OECD.
} 


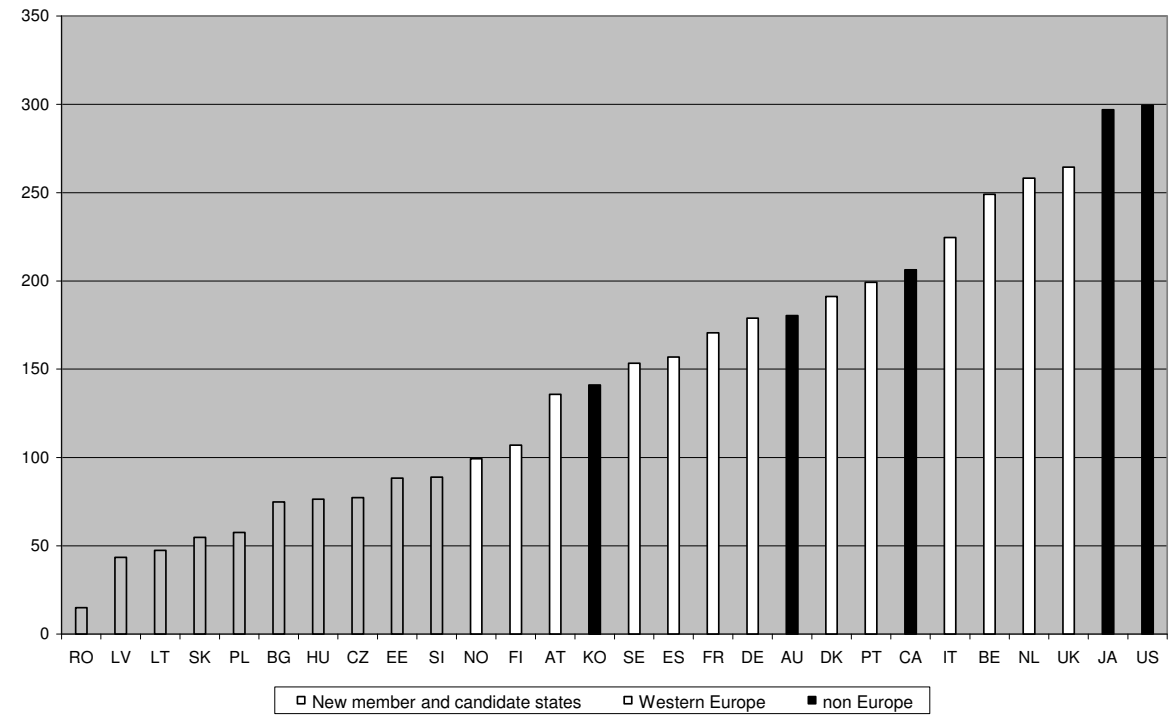

Figure 1: Household assets per GDP

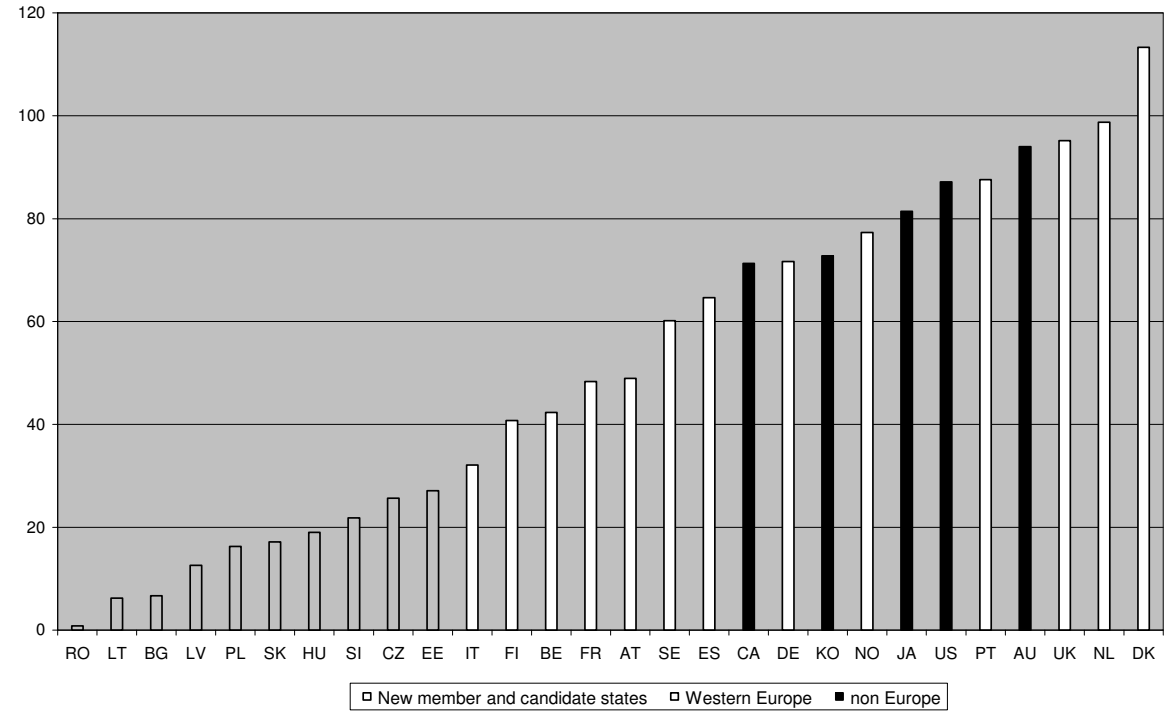

Figure 2: Household liabilities per GDP 


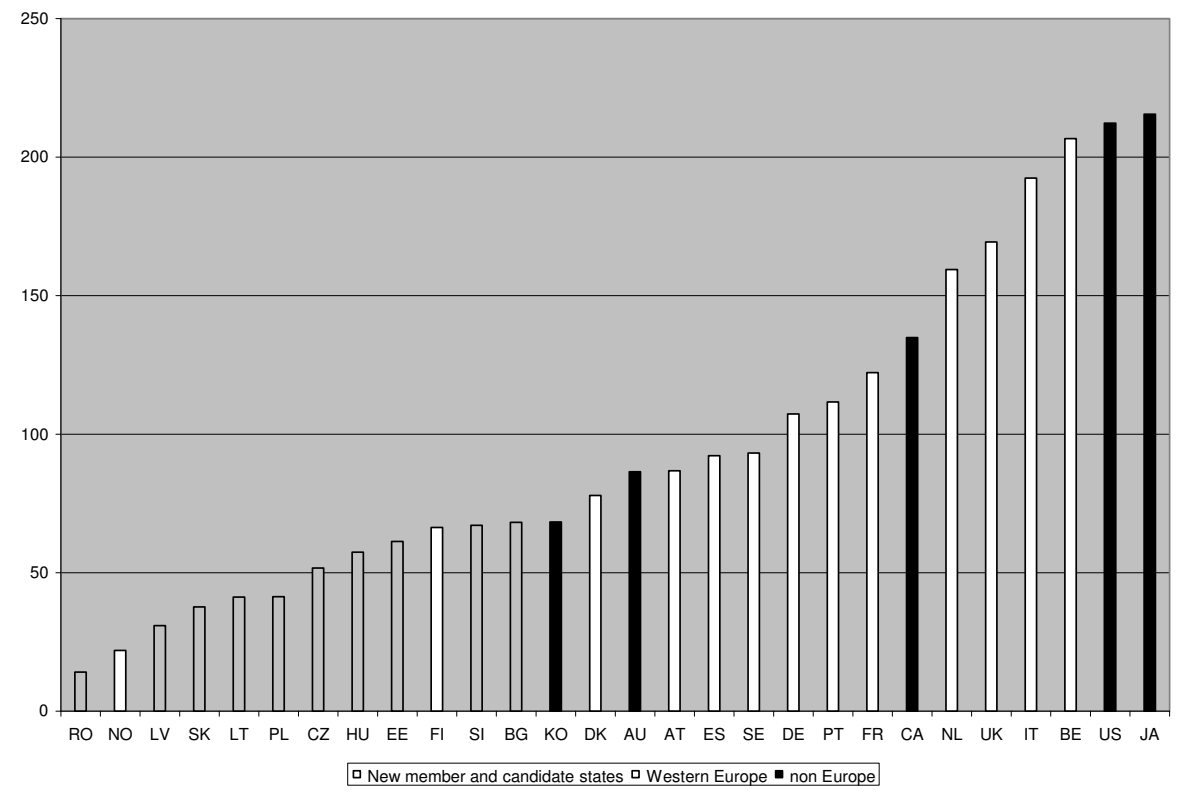

Figure 3: Household net wealth per GDP

Spain, Portugal, or Korea. Figure 2 plots the same measure of household liabilities, again showing that new member states and, to a smaller degree, less developed economies lag behind industrial economies in this respect. Finally, as Figure 3 shows, a similar though somewhat less pronounced pattern holds for overall household net worth.

It is also important to look at the time series behavior of these statistics. We use three countries as illustrations: two early catching-up countries, Spain and Portugal, plus Hungary (Figure 4). Spain exhibited a strong increase in assets and roughly constant liabilities until the late nineties, and then -likely driven by easier access to international credit -liabilities started to grow, while assets even decreased. In Portugal, both assets and liabilities were increasing, leading to an overall decline in net wealth. Finally, Hungary had an increase in assets throughout the entire period 1990-2004, while liabilities started to grow only after 2000, leading to a reversal in net wealth as well. We indeed see a general increasing trend both in assets and liabilities, mixed with cyclical and one-time effects like easing international borrowing constraints; while the development of net wealth is ambiguous.

Switching now to the composition of household balance sheets, Figure 5 shows that apart from Estonia, new member states have at least $40 \%$ share of currency, bank deposits and bonds (securities other than shares) in their asset holdings. Spain and Portugal also have such high numbers; while Austria, Japan, Korea and to a smaller extent, Belgium, Germany and Italy are more surprising examples of industrialized countries with a very high share. All other developed 


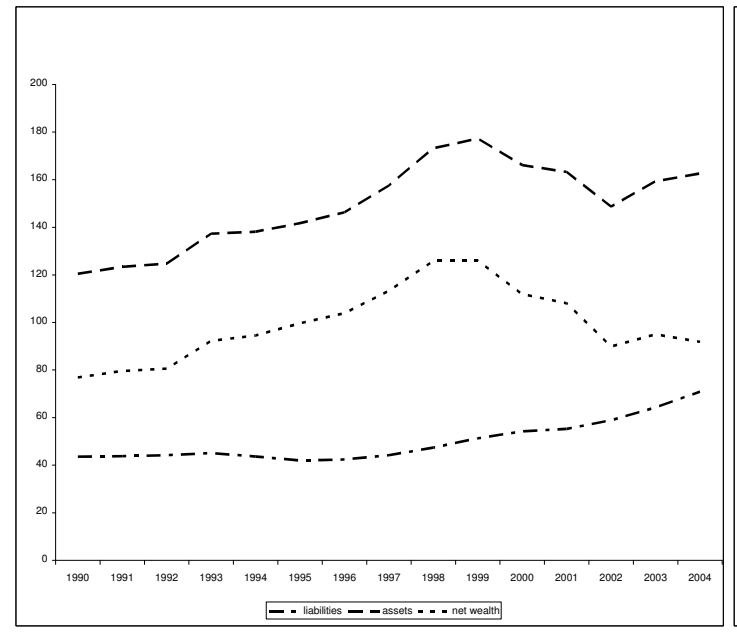

Panel A: Spain

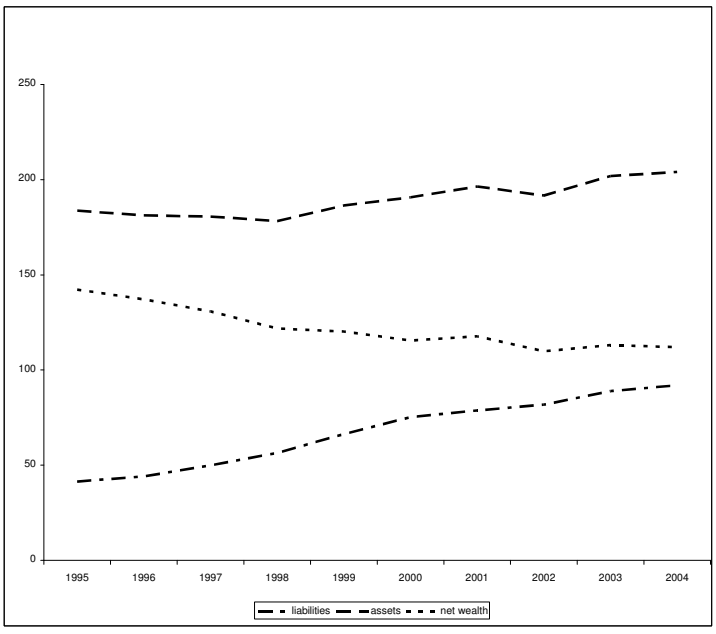

Panel B: Portugal

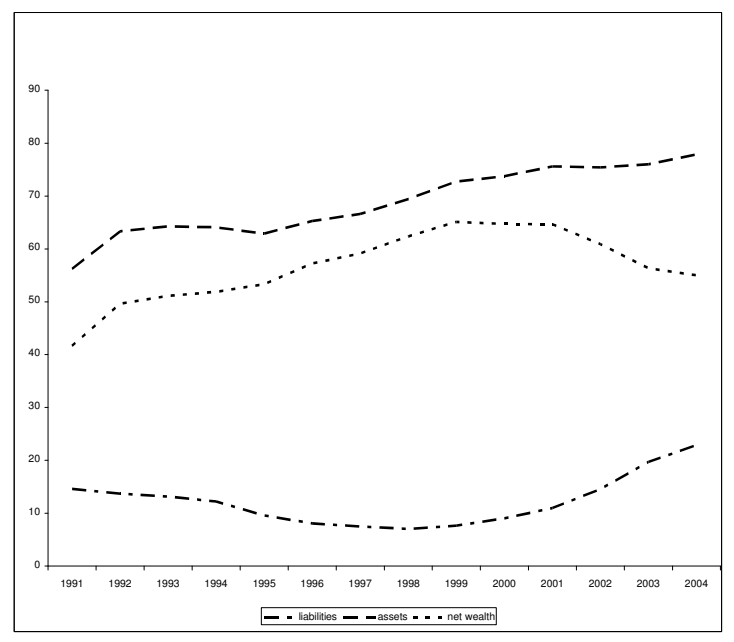

Panel C: Hungary

Figure 4: Time series evolution of household balance sheets

countries have substantially smaller shares, though it always exceeds $20 \%$.

This distinction remains true if one looks at the entire nineties: with the above exceptions (plus Finland for the early nineties), developed economies rarely had a share higher that $40 \%$, while new member states (with the exception of Estonia and Lithuania) never had a share below 40\%. A similar pattern emerges when we look at the ratio of net deposit-type holdings (net currency, deposit and bond holdings minus bank loans) to net wealth (Figure 6): apart from Estonia, new members states are at the high end of the distribution, together with Austria, Belgium, Italy, Japan and Korea. ${ }^{9}$

\footnotetext{
${ }^{9}$ These observations remain valid if we exclude bond holdings (item 3 of financial accounts statistics), and
} 


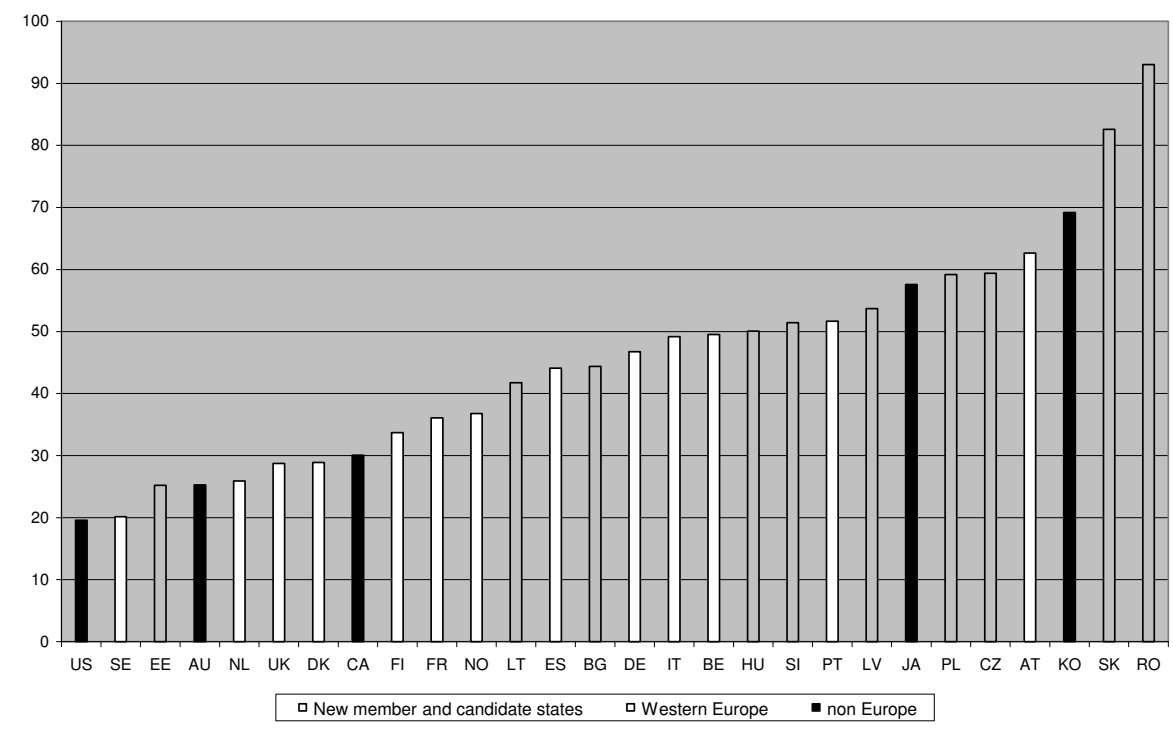

Figure 5: Currency, bank deposits and securities other than shares per household assets

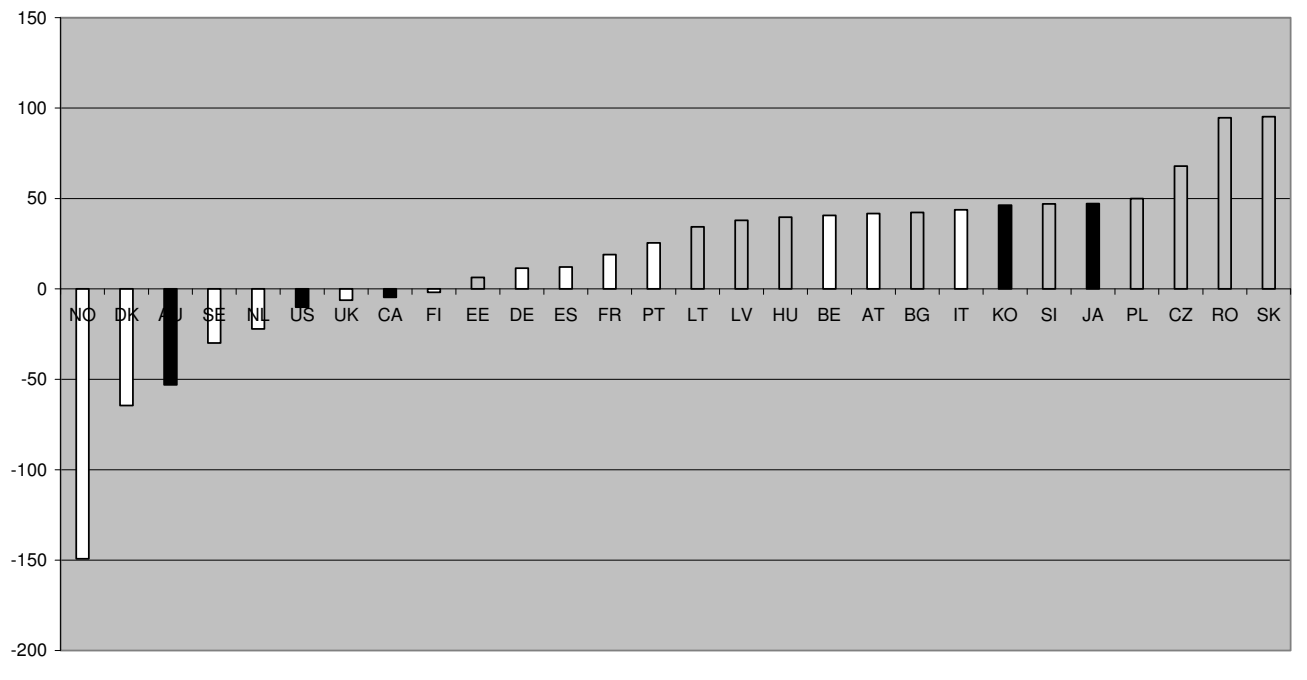

$\square$ New member and candidate states $\square$ Western Europe $~ n o n$ European

Figure 6: Net currency, bank deposits, loans and securities other than shares per household wealth 
We now discuss some stylized facts relating to the results of our model. It gives important predictions about employment, price and wage dynamics after nominal exchange rate shocks. In particular, a nominal appreciation leads to (1) an increase in wages; (2) a reallocation of labor from manufacturing to services; (3) an investment slowdown with a marked sectoral asymmetry: increase in service sector investment, fall in manufacturing; (4) an increase in the nontradedtraded relative price; (5) an overall consumption boom, accompanied by a deteriorating trade balance; (6) a temporary increase in real GDP. A depreciation would produce exactly the opposite of these effects.

Our model particularly matches the recent experience of Hungary (1999-2003), showing all the symptoms from above. While there were many different impulses coming from both monetary and fiscal policy, most of these impulses point in the same direction. In the language of the model, most changes were shocks to nominal wealth. Since our model has the same predictions for any such shock, it is not important (and also not feasible) to separate out the impact of nominal appreciation. Thus while the exact contribution of each shock is unclear, we feel confident that the final picture is consistent with the models predictions about an economy with excessive nominal wealth ("overvaluation"). The Appendix offers a detailed coverage of this episode.

At a more general level, these predictions are in line with the performance of exchange-rate based disinflations, and its reverse conclusions are relevant to price and wage dynamics after large devaluations. Rebelo and Végh (1995) find the following main stylized facts of exchange rate based stabilization programs: (1) high economic growth, (2) which is dominantly fuelled by consumption, (3) slow price adjustment,(4) deteriorating trade balance. They also show some indicative evidence of a superior nontradable performance for Uruguay, Mexico, and cite Bufman and Leiderman (1995) as evidence for Israel. Burstein et al (2002) analyze large devaluation episodes, and find that (1) inflation is low relative to the depreciation, (2) the relative price of nontradables falls, (3) export and import prices (goods that are truly traded and not just tradable) track more closely with the exchange rate than the full CPI, (4) real GDP growth declines, and (5) there is a rise in the trade surplus.

consider cash, bank deposits and loans only. In fact, the pattern is even more clear-cut; with Austria, Japan and Korea being the sole set of exceptions among industrial countries. 


\section{The model}

\subsection{Consumers}

Consumers solve the following problem:

$$
\begin{aligned}
\max U_{0} & =E_{0} \sum_{t=0}^{\infty}\left(\frac{1}{1+\rho}\right)^{t}\left[\log C_{t}+\gamma \log \frac{H_{t}}{P_{t}}-\omega \frac{L_{t}^{1+\phi}}{1+\phi}\right] \\
\text { s.t. } A_{t} & =W_{t} L_{t}-P_{t} C_{t}+H_{t-1}+\tau H_{t-1}+\left(1+i_{t-1}\right) \varepsilon_{t} b_{t-1},
\end{aligned}
$$

where $W L$ is aggregate labor income, $\tau H_{t-1}$ is a government transfer, ${ }^{10}$

$$
C=C_{T}^{\lambda} C_{N}^{1-\lambda}
$$

is the intratemporal utility of consumption. Consumers consume a mix of tradable and nontradable goods and take disutility from work. $P$ is the ideal price index associated with $C$ (see below) and $\rho$ is the worldwide discount rate, and also the rate of interest abroad. Changes in nominal wealth $(A)$ come either from the government $(\tau H)$ or from abroad. The latter requires households to be net savers (relative to the rest of the world).

Part of wealth is held as money, and the rest is invested (or borrowed) in foreign bonds $\left(b_{t}=a_{t}-H_{t} / \varepsilon_{t}\right)$. Foreign bonds are measured and fixed in euros (lowercase letters), while all other variables are in local currency (uppercase letters). The only source of uncertainty in the model comes from monetary policy: we want to consider the effects of an unexpected change of a (fixed) exchange rate $\left(\varepsilon_{t}\right)$. To ensure the long-run existence of a well-defined steady state, we assume a debt-dependent bond rate $i_{t}=i(b)$, as in Schmitt-Grohe and Uribe (2003). In fact, this assumption is also crucial for money to play a non-negligible role: without it, we would observe full consumption-smoothing and constant money holdings. The particular form is

$$
1+i(b)=1+\rho+d(a-h)
$$

where $d(\cdot)$ is a risk premium which is decreasing in its argument (recall that $a-h$ is the negative of debt), and $d(\bar{b})=0$. We work with the same functional form as Schmitt-Grohe and Uribe (2003): $d(b)=\psi\left(e^{-(b-\bar{b})}-1\right)$. We assume that individual households do not internalize the effect of their borrowing or lending on $i(\cdot)$, i.e. the debt premium depends on average (country

\footnotetext{
${ }^{10}$ What we assume here is that consumers get a transfer proportional to their money holdings. This makes sure that whether we implement the real model by fexible exchange rates or perfectly elastic money supply would be completely equivalent. One could also work with an exogenous transfer $T$. Then the choice of nominal implementation would have an effect on real money growth and the utility derived from money holdings, but all other real variables would be the same. We chose to work with $\tau H$.
} 
level) bond holdings.

The form of the utility function allows a sequential solution of the consumer problem: we first calculate the share of tradables and nontradables given current nominal expenditures (intratemporal step), and then we determine the optimal evolution of expenditures (intertemporal step).

The usual intratemporal optimization conditions imply that:

$$
\begin{aligned}
P C & =e C_{T}+P_{N} C_{N} \\
\frac{e C_{T}}{P_{N} C_{N}} & =\frac{\lambda}{1-\lambda} \\
P & =\underbrace{\lambda^{-\lambda}(1-\lambda)^{\lambda-1}}_{\chi} e^{\lambda} P_{N}^{1-\lambda} .
\end{aligned}
$$

The intertemporal problem is solved by writing down the Lagrangian:

$$
\mathfrak{L}=E_{0} \sum_{t=0}^{\infty}(1+\rho)^{-t}\left[\begin{array}{c}
\log C_{t}+\gamma \log \frac{H_{t}}{P_{t}}-\omega \frac{L_{t}^{1+\phi}}{1+\phi}+ \\
\theta_{t}\left[W_{t} L_{t}-P_{t} C_{t}+H_{t-1}+\tau H_{t-1}+\left(1+i_{t-1}\right) \varepsilon_{t} b_{t-1}-\varepsilon_{t} b_{t}-H_{t}\right]
\end{array}\right],
$$

and the first-order conditions are given by

$$
\begin{aligned}
\frac{1}{C_{t}} & =\theta_{t} P_{t} \\
\frac{\gamma}{H_{t}} & =\theta_{t}-\frac{1+\tau}{1+\rho} E_{t} \theta_{t+1} \\
\omega L_{t}^{\phi} & =\theta_{t} W_{t} \\
\theta_{t} \varepsilon_{t} & =\frac{1+i_{t}}{1+\rho} E_{t} \theta_{t+1} \varepsilon_{t+1} \\
\varepsilon_{t} b_{t}+H_{t} & =W_{t} L_{t}-P_{t} C_{t}+(1+\tau) H_{t-1}+\left(1+i_{t-1}\right) \varepsilon_{t} b_{t-1} .
\end{aligned}
$$

Dornbusch and Mussa (1975) use a similar framework to give a microfoundation of the $P C=V H$ relationship (nominal spending being proportional to money holdings): with a power Cobb-Douglas aggregate $\left(C^{\alpha}(H / P)^{\beta}\right)$, continuous time, constant inflation, no disutility of labor, and no bond markets, they show that $P C / H$ is indeed constant along the saddle path of the intertemporal optimization. In our work, however, inflation is changing through time. Given that the proportionality of $P C$ and $H$ is no longer true, we decided to use the more standard logarithmic Cobb-Douglas felicity function. This gives a less direct role of money in the consumption decision (the marginal utilities are separable), and it is also the standard choice of new-keynesian intertemporal models (see Woodford (2003), chapter 2.3.4 for consequences of nonseparable utility functions). 


\subsection{Producers}

Production functions are given by

$$
\begin{aligned}
Y_{T} & =L_{T}^{\beta} K_{T}^{1-\beta} \\
Y_{N T} & =L_{N}^{\alpha} K_{N}^{1-\alpha} .
\end{aligned}
$$

Since capital is sector specific while labor is assumed to be mobile across sectors, profit maximization implies

$$
\begin{aligned}
W & =\varepsilon \beta L_{T}^{\beta-1} K_{T}^{1-\beta}=P_{N} \alpha L_{N}^{\alpha-1} K_{N}^{1-\alpha} \\
R_{T} & =\varepsilon(1-\beta) L_{T}^{\beta} K_{T}^{-\beta} \\
R_{N} & =P_{N}(1-\alpha) L_{N}^{\alpha} K_{N}^{-\alpha} .
\end{aligned}
$$

Capital is predetermined at the beginning of time $t$, while labor can adjust within a period. Thus $K_{T}$ and $K_{N}$ always correspond to time $t-1$, while $L_{T}, L_{N}, W, R_{T}$ and $R_{N}$ are of time $t$. For example: $Y_{T}(t)=L_{T}^{\beta}(t) K_{T}^{1-\beta}(t-1)$.

We would not argue that the labor mobility assumption is fully realistic. One could also set up a model with slow labor adjustment. This would, however, excessively complicate the model, while the other two adjustments are vital to our analysis (for a real effect of nominal shocks, we need to have slow adjustment of nominal spending; and slow capital adjustment is necessary to analyze investment behavior). As for capital adjustment, we consider two separate $q$-theories in the two sectors, like Balsam and Eckstein (2001).

A third, hidden assumption on adjustments is the immediate and full pass-through of the nominal exchange rate into tradable prices. It is well-documented that the pass-through of exchange rate movements into tradable prices is far from full and immediate. Our focus, however, is essentially on the adjustment of the economy to a change in tradable prices. For this reason, similarly to most of the open economy macro literature, we work with a perfect pass-through into tradable prices.

\subsection{Investment}

One of the cornerstones of the "standard", "long-run" Balassa-Samuelson model (the one advocated by chapter 4 of the Obstfeld-Rogoff textbook) is the full mobility of capital. It implies that there is a common rental rate across sectors, which also equals the international rental rate. However, this implies a very fast and also mechanical capital accumulation and adjustment process. If we add the standard labor fexibility assumption $\left(W_{T}=W_{N}\right)$, the real exchange 
rate (traded-nontraded relative price) is fully supply-determined. The transformation curve is linear, and nominal variables (or preferences) have no effect on relative prices, only on quantities. For this reason, we assume that capital is sector specific, and investment is subject to adjustment costs, which makes its response gradual:

$$
\begin{aligned}
\max V_{0}^{x} & =E_{0} \sum_{t=0}^{\infty}(1+\rho)^{t}\left[\frac{R_{X}(t) K_{X}(t-1)}{\varepsilon_{t}}-I_{X}(t)-\frac{\delta_{X}}{2} \frac{I_{X}(t)^{2}}{K_{X}(t-1)}\right] \\
\text { s.t. } K_{X}(t) & =K_{X}(t-1)+I_{X}(t),
\end{aligned}
$$

where $X=T, N$. This is the standard $q$ problem, and the first-order conditions are

$$
\begin{aligned}
& q_{X}(t)=1+\delta_{X} \frac{I_{X}(t)}{K_{X}(t-1)} \\
& q_{X}(t)=(1+\rho)^{-1} E_{t}\left(q_{X}(t+1)+\frac{R_{X}(t+1)}{\varepsilon_{t+1}}+\frac{\delta_{X}}{2}\left(\frac{I_{X}(t+1)}{K_{X}(t)}\right)^{2}\right) .
\end{aligned}
$$

Here $q_{X}$ is the dynamic multiplicator (co-state variable). Rearranging the conditions yields

$$
\begin{aligned}
K_{X}(t) & =\left(1+\frac{q_{X}(t)-1}{\delta_{X}}\right) K_{X}(t-1) \\
q_{X}(t) & =\frac{1}{1+\rho} E_{t}\left(q_{X}(t+1)+\frac{R_{X}(t+1)}{\varepsilon_{t+1}}+\frac{\left(q_{X}(t+1)-1\right)^{2}}{2 \delta_{X}}\right) .
\end{aligned}
$$

\subsection{Equilibrium}

Let us introduce the term $X=P C$, which is -as can be seen from (1) -nominal expenditure. From (4) and (7) we get

$$
\frac{\varepsilon_{t}}{X_{t}}=\frac{1+i_{t}}{1+\rho} E_{t} \frac{\varepsilon_{t+1}}{X_{t+1}} .
$$

The other equilibrium conditions are

$$
\begin{aligned}
K_{X}(t) & =\left(1+\frac{q_{X}(t)-1}{\delta_{X}}\right) K_{X}(t-1) \\
q_{X}(t) & =\frac{1}{1+\rho} E_{t}\left(q_{X}(t+1)+\frac{R_{X}(t+1)}{\varepsilon_{t+1}}+\frac{\left(q_{X}(t+1)-1\right)^{2}}{2 \delta_{X}}\right) \\
A_{t} & =W_{t} L_{t}-X_{t}+(1+\tau) H_{t-1}+\left(1+i_{t-1}\right) \varepsilon_{t} b_{t-1} .
\end{aligned}
$$

The equations for $K_{X}$ and $q_{X}$ are in foreign currency, which means that the nominal exchange rate $\varepsilon$ does not directly enter those expressions. Let us transform the rest of the equilibrium conditions into foreign currency as well. Introducing $x=X / \varepsilon, h=H / \varepsilon, a=A / \varepsilon, r_{X}=R_{X} / \varepsilon, w=$ 
$W / \varepsilon$ yields

$$
\begin{aligned}
\frac{1}{x_{t}} & =\frac{1+i_{t}}{1+\rho} E_{t} \frac{1}{x_{t+1}} \\
a_{t} & =\frac{A_{t}}{\varepsilon}=w L-x+(1+\tau) h_{t-1} \frac{\varepsilon_{t-1}}{\varepsilon_{t}}+\left(1+i_{t-1}\right) b_{t-1} .
\end{aligned}
$$

Working entirely in foreign currency from here on; the dynamics are summarized by ${ }^{11}$

$$
\begin{aligned}
K_{N}(t) & =\left(1+\frac{q_{N}(t)-1}{\delta_{N}}\right) K_{N}(t-1) \\
K_{T}(t) & =\left(1+\frac{q_{T}(t)-1}{\delta_{T}}\right) K_{T}(t-1) \\
q_{N}(t) & =(1+\rho)^{-1} E_{t}\left(q_{N}(t+1)+r_{N}(t+1)+\frac{\left(q_{N}(t+1)-1\right)^{2}}{2 \delta_{N}}\right) \\
q_{T}(t) & =(1+\rho)^{-1} E_{t}\left(q_{T}(t+1)+r_{T}(t+1)+\frac{\left(q_{X}(t+1)-1\right)^{2}}{2 \delta_{X}}\right) \\
a_{t} & =w_{t} L_{t}-x_{t}+(1+\tau) h_{t-1} \frac{\varepsilon_{t-1}}{\varepsilon_{t}}+\left(1+\rho+d\left(a_{t-1}-h_{t-1}\right)\right)\left(a_{t-1}-h_{t-1}\right) \\
\frac{1}{x_{t}} & =\frac{1+\rho+d\left(a_{t}-h_{t}\right)}{1+\rho} E_{t} \frac{1}{x_{t+1}} .
\end{aligned}
$$

(12) - (17) is a system of six equations for seven variables: $K_{N}, K_{T}, q_{N}, q_{T}, a, x$ and $\varepsilon$ (the other variables $h, w, L$, and $r_{X}$ are functions of these seven). A seventh equation is given by monetary policy. One assumption is that the change in the nominal exchange rate is constant, i.e. $\frac{\varepsilon_{t-1}}{\varepsilon_{t}}=\mu$. Under fixed exchange rates or a crawling peg, we have six equations with six endogenous variables, and three forcing variables: $\tau, \varepsilon$ and $\mu$, which could be viewed as vehicles of monetary and fiscal policy. For a steady state to exist, monetary policy must satisfy $(1+\tau) \mu=1$ in the long run. In case of a constant long-run nominal exchange rate, this implies zero long-run money growth. In general, any exchange rate level and rate of devaluation are consistent with the long-run steady state, with an appropriate money growth process.

\footnotetext{
${ }^{11}$ For notational clarity, we will use $K, K_{T}$ and $K_{N}$ for the capital stock and $L$ for aggregate labor supply, while $k_{N}$ and $k_{T}$ denote capital-labor ratios.
} 
The steady state conditions are

$$
\begin{aligned}
\bar{q}_{N} & =\bar{q}_{T}=1 \\
\bar{r}_{N} & =\bar{r}_{T}=\frac{1}{\beta}=\rho \\
\bar{w} \bar{L} & =\bar{x}-\rho \bar{b} \\
\omega \bar{x} & =\bar{w} \bar{L}^{-\phi} \\
\bar{h} & =\gamma \bar{x} \frac{1+\rho}{\rho} \\
\bar{a} & =\bar{b}+\bar{h} .
\end{aligned}
$$

Notice that the exchange rate does not influence $\bar{r}_{X}$. Consequently, all the technology-determined variables are independent of the path of the nominal exchange rate, which also pins down all demand-side variables. ${ }^{12}$

In what follows, we consider three alternative policy regimes: fexible exchange rates (and fixed money supply: $\tau=0$ ), perfectly elastic money supply (and fixed exchange rates: $\mu=0$ ), and a currency board (fixed exchange rates and no exogenous money growth). The next section develops the fexible exchange rate and the elastic money supply regimes in details and shows that the path of real variables is identical to a model where money has no role $(\gamma=0)$. For the currency board $\mu=0$ and $\tau=0$ in every period. As the government does not print money and there is no change in the external value of the local currency, any increase in money demand must be financed through a money infbw from the rest of the world. It can happen through borrowing or a trade surplus. As we will demonstrate, this leads to deviations from the real model, which is not the case for the two fexible regimes.

These assumptions are characteristic of the gold standard system, or currency board regimes. The relevance of these frameworks for euro adoption is due to the fact that a monetary union is essentially a currency board regime. Our model can thus address the real effects of the choice of the euro conversion rate. Moreover, a de jure flexible regime might exhibit less than perfectly elastic money supply (in case of fixed exchange rates) or less than perfectly fbating exchange rates. In that case nominal shocks (money print or exchange rate movements) would drive the economy away from its real path.

\footnotetext{
${ }^{12}$ This is a point where our assumption of money transfers being proportional to existing money holdings is influential. If money transfer were exogenous, here we would get that $\bar{h}=\frac{\gamma \bar{x}}{\rho+\varepsilon}$, so money and wealth would depend on the steady state rate of devaluation.
} 


\section{Flexible exchange rates}

Let us assume that foreigners are unwilling to hold domestic currency. Under fexible exchange rates, the central bank is not committed to any exchange rate behavior, which implies that it is unwilling to take an open position in the local currency either. Under these assumptions, a fexible exchange rate regime implies a constant (exogenous) money stock. The regime with constant money could be labelled as "money growth targeting", while a constant exchange rate (with the appropriate money growth) is "exchange rate targeting".

We will start with the case when money is constant: setting $\tau=0$ and $H_{t} \equiv H$ in (12)-(17), the dynamic system becomes

$$
\begin{aligned}
K_{N}(t) & =\left(1+\frac{q_{N}(t)-1}{\delta_{N}}\right) K_{N}(t-1) \\
K_{T}(t) & =\left(1+\frac{q_{T}(t)-1}{\delta_{T}}\right) K_{T}(t-1) \\
q_{N}(t) & =(1+\rho)^{-1} E_{t}\left(q_{N}(t+1)+r_{N}(t+1)+\frac{\left(q_{N}(t+1)-1\right)^{2}}{2 \delta_{N}}\right) \\
q_{T}(t) & =(1+\rho)^{-1} E_{t}\left(q_{T}(t+1)+r_{T}(t+1)+\frac{\left(q_{X}(t+1)-1\right)^{2}}{2 \delta_{X}}\right) \\
b_{t} & =a_{t}-h_{t}=a_{t}-h_{t-1} \frac{\varepsilon_{t-1}}{\varepsilon_{t}}=w_{t} L_{t}-x_{t}+\left(1+\rho+d\left(b_{t-1}\right)\right) b_{t-1} \\
\frac{1}{x_{t}} & =\frac{1+\rho+d\left(b_{t}\right)}{1+\rho} E_{t} \frac{1}{x_{t+1}} .
\end{aligned}
$$

while the steady state conditions remain the same. Notice that this system is free from the nominal exchange rate; thus it is no longer stochastic.

Alternatively, setting $\varepsilon_{t}=\bar{\varepsilon}$ and $H_{t}=(1+\tau) H_{t-1}$, (16) becomes

$$
b_{t}=a_{t}-h_{t}=a_{t}-(1+\tau) h_{t-1}=w_{t} L_{t}-x_{t}+\left(1+\rho+d\left(b_{t-1}\right)\right) b_{t-1},
$$

which is indeed identical to (22).

Notice that (18)-(23) describe an entirely real system (this would not hold under a currency board, where $H_{t} \neq \bar{H}$ ). This is the same as the nonmonetary version of the model, where consumers solve

Here all variables are measured in consumption units, i.e. we normalize the (real) price of consumption to unity. This is the same as measuring everything in foreign units, so the bond rate is indeed $1+\rho+d(b)$. Again, there is no uncertainty in this model. The intertemporal 
problem is now represented by the Lagrangian

$$
\mathfrak{L}=\sum_{t=0}^{\infty}(1+\rho)^{-t}\left[\log c_{t}-\omega \frac{L_{t}^{1+\phi}-1}{1+\phi}+\theta_{t}\left[w_{t} L_{t}-p_{t} c_{t}+\left(1+i_{t-1}\right) b_{t-1}-b_{t}\right]\right] .
$$

The first-order conditions are

$$
\begin{aligned}
\frac{1}{p_{t} c_{t}} & =\theta_{t} \\
\omega L_{t}^{\phi} & =\theta_{t} w_{t} \\
\theta_{t} & =\frac{\theta_{t+1}}{1+\rho}\left(1+i_{t}\right) \\
b_{t} & =w_{t} L_{t}-p_{t} c_{t}+\left(1+\rho+d\left(b_{t-1}\right)\right) b_{t-1} .
\end{aligned}
$$

The production and investment side remains the same as in the nominal case. Rewriting (24):

$$
x_{t}=x_{t+1} \frac{1+\rho}{1+\rho+d\left(b_{t}\right)} .
$$

As all the other static and dynamic equations remain the same, this establishes our first general result:

Proposition 1 Both he flexible exchange rate and the elastic money supply economy implement the real version of the model.

To determine the evolution of $\varepsilon$ under fexible exchange rates, remember that

$$
\begin{aligned}
\frac{\gamma}{H_{t}} & =\frac{1}{X_{t}}-\frac{1+\tau}{1+\rho} \frac{1}{X_{t+1}} \\
\frac{\gamma}{h_{t}} & =\frac{1}{x_{t}}-\frac{1+\tau}{1+\rho} \frac{1}{x_{t+1}} \frac{\varepsilon_{t}}{\varepsilon_{t+1}}
\end{aligned}
$$

thus

$$
\frac{\varepsilon_{t+1}}{\varepsilon_{t}}=\frac{1}{1-\frac{\gamma x_{t}}{H} \varepsilon_{t}} \frac{1}{1+\rho+d\left(b_{t}\right)} .
$$

Given $\varepsilon_{t}, x_{t}$ and $b_{t}$, this indeed gives the law of motion for $\varepsilon$. Combining with (23) we get

$$
\begin{aligned}
\frac{\varepsilon_{t+1}}{\varepsilon_{t}} & =\frac{1}{1-\frac{\gamma x_{t}}{H} \varepsilon_{t}} \frac{x_{t}}{(1+\rho) x_{t+1}} \\
x_{t+1} \varepsilon_{t+1} & =\frac{H}{H-\gamma x_{t} \varepsilon_{t}} \frac{x_{t} \varepsilon_{t}}{1+\rho} \\
X_{t+1} & =\frac{H}{H-\gamma X_{t}} \frac{X_{t}}{1+\rho} \\
1+\rho-\frac{\gamma(1+\rho)}{H} X_{t} & =\frac{X_{t}}{X_{t+1}} .
\end{aligned}
$$


Now $x_{t}$ is constant in the long run. So if we are looking for such a nominal implementation of the real model where $\varepsilon_{t}$, the nominal exchange rate is constant in the long run (a "no bubble" condition), then we must have $X_{t} \equiv H \frac{\rho}{\gamma(1+\rho)}=\bar{X} \cdot{ }^{13}$ The equilibrium nominal exchange rate path is such that nominal expenditures remain constant in local currency, so $\hat{x}=\hat{h}=-\hat{\varepsilon}$. Assuming that the euro value of expenditures increases during convergence, an equilibrium nominal appreciation follows, which proves our second result:

Proposition 2 Convergence implies an equilibrium nominal appreciation.

Under exchange rate targeting, $\varepsilon=\bar{\varepsilon}$ and

$$
\begin{aligned}
\frac{\gamma}{H_{t}} & =\frac{1}{X_{t}}-\frac{1+\tau}{1+\rho} \frac{1}{X_{t+1}} \\
\frac{\gamma(1+\rho)}{H_{t}} & =\frac{1+\rho}{X_{t}}+\frac{H_{t+1}}{H_{t} X_{t+1}} \\
\frac{H_{t+1}}{X_{t+1}} & =(1+\rho)\left(\frac{H_{t}}{X_{t}}-\gamma\right) \\
\frac{H_{t+1}}{X_{t+1}}-\frac{\gamma(1+\rho)}{\rho} & =(1+\rho)\left(\frac{H_{t}}{X_{t}}-\frac{\gamma(1+\rho)}{\rho}\right) ;
\end{aligned}
$$

so again, if we rule out explosive money growth paths, we must have $h=\frac{\gamma(1+\rho)}{\rho} x$, or equivalently, $X=\frac{\gamma(1+\rho)}{\rho} H=\bar{X}$. The dynamics of real money (the euro value of local currency) is thus the same under the two monetary arrangements. ${ }^{14}$

What happens to the equilibrium real exchange rate during convergence? It consists of two components: the relative price of nontradables and the nominal exchange rate. As $\hat{\varepsilon}=-\hat{x}$, there is an equilibrium nominal appreciation. On the other hand, one can show that the initial relative price gap depends positively on the initial gap in expenditures and traded capital, negatively on the nontraded capital gap, but the coeffi cient of expenditures is less than $1^{15}$ So even if all gaps are negative, the relative price has an ambiguous sign. As the real exchange rate equals $\hat{p}_{N}+\hat{\varepsilon}$, it depends negatively on the gap in expenditures and nontradable capital, and positively on the tradable capital gap; thus it is more likely that convergence implies a real appreciation than an increase in the nontradable relative price. We will indeed see a numerical example when there is a real appreciation but a relative price decline throughout the convergence process.

\footnotetext{
${ }^{13}$ If $X_{t}>\frac{H}{\gamma} \rho$ then $X_{t+1}>X_{t}$, so it remains higher than $H \frac{\rho}{\gamma(1+\rho)}$ and thus increases without bounds; while it decreases without bounds if it starts below $H \frac{\rho}{\gamma(1+\rho)}$.

${ }^{14}$ This is where the assumption of exogenous money transfers would make a difference. The reason is that consumers in a flexible exchange rate economy do realize that the euro value of their money holdings will change over time; while consumers in the fixed exchange rate regime take money growth as exogenous. The nonmonetary part of consumer welfare is still the same in the two implementations, but the monetary part differs.

${ }^{15}$ This follows from the loglinearization presented in the Appendix: after solving the system (28)-(35), it is straightforward to check the signs of $\hat{x}, \hat{K}_{N}$ and $\hat{K}_{T}$.
} 


\section{The currency board}

To understand the mechanics of the currency board regime, recall that the change in consumer wealth (measured in domestic currency) is given by

$$
\begin{aligned}
A_{t}= & W_{t} L_{t}-P_{t} C_{t}+(1+\tau) H_{t-1}+\left(1+i\left(b_{t-1}\right)\right) \varepsilon_{t} b_{t-1} \\
A_{t}= & Y_{T}+P_{N} Y_{N}-R_{T} K_{T}-R_{N} K_{N}-C_{T}-P_{N} C_{N}+(1+\tau) H_{t-1} \\
& +\left(1+i\left(b_{t-1}\right)\right) \frac{\varepsilon_{t}}{\varepsilon_{t-1}} \varepsilon_{t-1} b_{t-1} \\
H_{t}+\varepsilon_{t} b_{t}= & \left(Y_{T}-C_{T}\right)-R_{T} K_{T}-R_{N} K_{N}+I\left(b_{t-1}\right) \varepsilon_{t-1} b_{t-1}+\tau H_{t-1}+H_{t-1} \\
& +\varepsilon_{t-1} b_{t-1} .
\end{aligned}
$$

This is purely an accumulation identity: the change in assets is equal to GNP minus expenditures, plus government transfers. GNP is the sum of traded and nontraded production (GDP), plus the interest income fbw on NFA holdings, minus capital rents (that belongs to foreigners). Since the nontraded sector is in equilibrium, the value of nontraded production must equal the value of nontraded consumption. Expressing the change in money holdings:

$$
H_{t}-H_{t-1}=-\left(\varepsilon_{t} b_{t}-\varepsilon_{t-1} b_{t-1}\right)+\left(Y_{T}-C_{T}\right)+I\left(b_{t-1}\right) \varepsilon_{t-1} b_{t-1}-R_{T} K_{T}-R_{N} K_{N}+\tau H_{t-1} .
$$

Change in money holdings thus equals the change in foreign assets, plus the excess production of tradables, plus the income from NFA holdings, minus capital rents, plus the exogenous term $\tau H$.

Under the currency board arrangement, the government is prohibited from printing money, so $\tau=0$, and naturally, $\varepsilon$ is fixed. Just like in the fexible exchange rate case, we assume that foreigners cannot use the local currency for their transactions, so they do not accept it at all. How can consumers still increase the domestic money stock? They receive foreign currency (euros) for their trade surplus and foreign investment income (the current account balance), which they take to their own central bank. The central bank takes the euros, adds them to its foreign reserves, and issues domestic money in return. An alternative is to borrow from the rest of the world $\left(-\left(\varepsilon_{t} b_{t}-\varepsilon_{t-1} b_{t-1}\right)\right)$ in euros and again, exchange it to domestic money through the central bank. In both ways the rest of the world does not need to take any positions in the currency board countrys local currency. Realizing that $H$ equals the foreign reserves of the central bank, one can reinterpret $A$ as the net foreign asset position of the economy. Then (25) is simply the equality of the current and the financial account (including changes in reserves).

Now we compare the dynamic system describing the currency board case to the fexible exchange rate model (the real equilibrium). Equations (12), (14) and (17) are the same in the 
two cases $(18,20$ and 22 in the real model). The only difference is (16). Using that $\tau=0$ and $\varepsilon$ is constant, it now becomes

$$
b_{t}=w_{t} L_{t}-x_{t}+\left(1+\rho+d\left(b_{t-1}\right)\right) b_{t-1}-\left(h_{t}-h_{t-1}\right)
$$

Recalling that

$$
\frac{\gamma}{h_{t}}=\frac{1}{x_{t}}-\frac{1}{1+\rho} E_{t} \frac{1}{x_{t+1}},
$$

it is immediate that (22) and (26) differ, thus we get our third result:

Proposition 3 The currency board dynamic system is different from the flexible exchange rate regime.

What does a revaluation do in a currency board economy? Just before the revaluation, consumers hold $b_{t-1}$ foreign bonds and $H_{t-1}$ units of local currency. Evaluated at the initial exchange rate, household wealth is $a_{t-1}=b_{t-1}+\varepsilon H_{t-1}$; while after the revaluation, it becomes $a_{t-1}^{\prime}=b_{t-1}+\varepsilon^{\prime} H_{t-1}>a_{t-1}$. Consequently, a revaluation (or a stronger conversion rate) is equivalent to a wealth shock of $\Delta \varepsilon H$. As wealth is a regular state variable, a wealth shock leads to a full dynamic response of real variables.

In a perfectly elastic money supply regime, the same wealth shock is immediately neutralized by a change in the per period money transfer; while if a central bank of a fexible exchange rate economy prints money, that is immediately offset by a currency depreciation. This is summarized in our fourth result:

Proposition 4 The level of the exchange rate or the size of the money stock has a real effect in a currency board regime; while it is neutral in the nominal implementation of the real model.

It is important to clarify whether a change in the exchange rate is sensible within a currency board framework. Literally speaking, a currency board cannot revalue its currency (unless it receives foreign grants to increase its reserves). It can nevertheless devalue and set aside some of the previous reserves. The question is now what they do with those excess funds. One possibility is to buy import goods from that directly -or give to the government who could again do the same. In this case the extra funds are given to foreigners, in return for imported goods.

If those excess funds are converted to local currency, then there is no change in the euro value of the local currency, just a reshuffl ing of who owns the money. If the unused reserves are distributed in proportion to local currency holdings, there is no change at all, while if the mechanism is different, there is again redistribution within the country. In a representative agent world (where a redistribution is neutral on aggregates), all these cases imply no real effects at all. 
A more interesting example is the conversion rate around German unification - as most East Germans had their savings in local currency (cash or bank deposits), this was purely a transfer/wealth effect, exactly in the spirit of our model. Not surprisingly, the East German economy showed strong symptoms of overvaluation, in response to a very strong conversion rate. The return of the UK to the gold standard after WWI and the euro conversion rate are similar examples.

Let us stress that one cannot use this framework to calculate an optimal conversion rate. In terms of consumer welfare (no matter whether we take into account the money part of it or not), the stronger the entry rate, the better. Again, this is due to the pure wealth transfer. In reality, there should be constraints on how much foreign currency the rest of the world is willing to give for a local currency, but such considerations are not part of our framework. Besides, governments might care for certain subgroups (like exporters), which would again limit the case for a strong entry rate. Nevertheless, our model does produce lasting and sizable real consequences of different entry rates.

\section{$6 \quad$ Policy exercises}

Our objective is twofold: on the one hand, we want to show that our model delivers sizable real effects under plausible parameter values; and on the other hand, most of the impulse responses are hard to sign analytically.

\subsection{Choice of parameters}

For illustrative purposes, let us fix all the parameters:

$\alpha=0.8$-labor intensity of the nontraded sector.

$\beta=0.5$-labor intensity of the traded sector. All this starting assumption does is to assume that $\alpha>\beta$, which is a standard choice, though it might not hold in certain countries. ${ }^{16}$ To explore its role in delivering results, we also run two additional simulations with $\alpha=0.5$ and 0.3 .

$\lambda=1 / 3$-expenditure share on tradables. This is a reasonable assumption, particularly if we take into account that traded prices also have large service components.

$\rho=r^{*}=0.05$-required real rate of return on capital. Assuming that one year is a unit time interval, then it means $5 \%$ annually.

\footnotetext{
${ }^{16}$ The equilibrium nominal appreciation result and the impact of a nominal appreciation within a currency board economy is independent from the ranking of $\alpha$ and $\beta$. The equilibrium real appreciation and particularly the increase in the nontradable relative price is sensitive to this assumption.
} 
$\delta_{N}=\delta_{T}=5$-the investment adjustment cost parameter. This number can be chosen to match a priori expectations about the speed of capital adjustment. Our choice means that the half-life of a proportional innovation to the capital stock in the real model $\left(\hat{K}_{N}=\hat{K}_{T}<0\right.$, $d b=0)$ is 15 years.

$\psi=0.02$. This risk premium parameter is higher than the choice (0.000742) of SchmittGrohe and Uribe (2003). In case of an emerging economy, it is not unreasonable to assume a risk premium that is more responsive to foreign debt than in an industrial economy. Under our parameter choices, annual GDP is $\bar{w}=5$, so for a level of excess foreign debt of $b-\bar{b}=-0.5(10 \%$ of GDP) the risk-adjusted interest rate becomes $\rho+\psi\left(e^{0.5}-1\right) \approx 0.05+0.013=0.063$. The contribution of the risk premium is overall reasonable. For our purposes, the most important consequence of choosing $\psi$ is the speed of adjustment following a wealth shock. In the real model with exogenous labor income $(\hat{w}=\hat{L} \equiv 0)$, the wealth-expenditure block becomes a saddle-path stable system with an eigenvalue of 0.75558 (a half-life of 2.5 years). ${ }^{17}$

$\gamma=0.05-$ the relative weight of real money in the per period utility function. Based on the steady state relationship $\frac{\bar{h}}{\bar{w}}=\frac{\gamma(1+\rho)}{\rho}=1.05$, our parameters mean that steady state money holdings are equal to $105 \%$ of annual labor income. The choice of $\gamma$ also influences the speed of adjustment following a wealth shock in the nominal model. Again with exogenous labor income, the half-life of a wealth shock becomes 4.5 years. ${ }^{18}$ This is somewhat higher than for the real model, but the overall contribution of the nominal friction is reasonable.

$\phi=5$-labor supply elasticity.

$\bar{b}=0$-this means that the country has a zero net foreign asset position in the long-run, $100 \%$ of its assets are local (money), and total assets equal 105\% of annual national income (which is just the wage).

$\omega=1$-with such a weight on labor disutility, the steady state labor supply becomes 1 .

$\hat{K}_{N}(0)=\hat{K}_{T}(0)=-0.5$-initial capital stocks. ${ }^{19}$

$d a_{0}=\bar{a} / 2=2.625$-this means that initial wealth is $50 \%$ of its long-run level. Since $\bar{b}=0$, we have $\bar{a}=\bar{h}=(1+\rho) \bar{w}$, so $d a_{0}$ is $52.5 \%$ of steady state GNP. Under our parameter choice, $\hat{w}_{0} \approx-0.25$ in the both models, so initial wealth is roughly $66.6 \%$ of initial GNP.

\footnotetext{
${ }^{17}$ In this case $d b_{t}=-\bar{x} \hat{x}_{t}-\psi \bar{b} d b_{t-1}+(1+\rho) d b_{t-1}$ and $\hat{x}_{t}=\hat{x}_{t+1}+\frac{\psi}{1+\rho} d b_{t}$.

${ }^{18}$ In this case $d a_{t}=-\bar{x} \hat{x}_{t}-\psi \bar{b}\left(d a_{t-1}-\bar{h} \hat{h}_{t-1}\right)+(1+\rho) d a_{t-1}-\rho \bar{h} \hat{h}_{t-1}, \hat{x}_{t}=\hat{x}_{t+1}+\frac{\psi}{1+\rho}\left(d a_{t}-\bar{h} \hat{h}_{t}\right)$ and $\hat{h}_{t}=\frac{\rho(1+\rho)}{\rho(1+\rho)+\psi h} \hat{x}_{t}+\frac{\psi}{\rho(1+\rho)+\psi h} d a_{t}$.

${ }^{19}$ Clearly such a large deviation from steady state is inconsistent with the loglinear approximation. Given that the numerical solution of the exact system is problematic (due to its saddle path nature), we still believe that our numerical exercises are good illustrations of the theoretical results.
} 


\subsection{Signing impulse responses}

The transition matrix (both in the nominal and the real case) must have three convergent and three divergent eigenvalues, since the system is pinned down by three initial conditions (for capital in each of the sectors and wealth) and three terminal conditions (coming from the transversality conditions of consumer and investor optimization). Denote the three eigenvectors corresponding to the convergent roots by $\mathbf{v}_{1}, \mathbf{v}_{2}$ and $\mathbf{v}_{3}$. Then

$$
\left(\hat{K}_{N}, \hat{K}_{T}, d a, \hat{q}_{N}, \hat{q}_{T}, \hat{x}\right)_{t}=F_{1} \mathbf{v}_{1} \lambda_{1}^{t}+F_{2} \mathbf{v}_{2} \lambda_{2}^{t}+F_{3} \mathbf{v}_{3} e \lambda_{3}^{t}
$$

Coeffi cients $F_{1}, F_{2}$ and $F_{3}$ are set by the three initial conditions, so they can be expressed as linear combinations of $\hat{K}_{T 0}, \hat{K}_{N 0}$ and $d a_{0}$. Then $\hat{q}_{X 0}$ and $\hat{x}_{0}$ are also linear combinations, so

$$
\hat{x}_{0}=c_{0} \cdot d a_{0}+c_{1} \cdot \hat{K}_{N 0}+c_{2} \hat{K}_{T 0}
$$

where $c_{0}, c_{1}$ and $c_{2}$ are functions of the two eigenvectors. One can examine the signs of $c_{0}, c_{1}$ and $c_{2}$ using $\mathbf{A} \mathbf{v}_{i}=\lambda_{i} \mathbf{v}_{i}$ (A is the transition matrix); and then one can sign the rest of the impact effects based on the loglinearization (presented in the Appendix). We have done this in a simpler version of the model (when there is no labor supply, no access to foreign borrowing or lending and capital is mobile across sectors but not internationally), but here we resort only to numerical exercises. In Table 1 , we briefly summarize the impact effect of changing $K_{N 0}, K_{T 0}, a_{0}$ alone, and also of a common capital shock $\left(\hat{K}_{N 0}=\hat{K}_{T 0}\right)$ on all relevant variables.

There is no difference in the directions of the changes between the real and nominal models, although the magnitudes in general differ (see the numerical results on the comparison of the two regimes). The signs are sensible and accord with economic logic. For example, an increase in wealth leads to higher spending $(x)$, thus higher consumption of both tradables and nontradables. This pushes the economy towards nontradables production, increasing its relative price and wages, and reallocating labor and investment towards that sector. Capital intensity decreases in nontradables, and increases in tradables and at the aggregate level. Regarding GDP, there is a decline in tradables and an increase in nontradables, plus their relative price may also change (in case of current price GDP). Overall, fixed price GDP falls while current price GDP increases.

The effects of a wealth shock directly apply to a permanent nominal appreciation within the gold standard, or the comparison of two euro conversion rates. This leads us to our fifth result:

Proposition 5 An economy with a stronger conversion rate will be tilted towards nontradables, and it will exhibit higher nominal spending, wages, nontradable prices and current account deficits etc. 


\begin{tabular}{|c|c|c|c|c|c|c|c|c|}
\hline & \multicolumn{2}{|c|}{ wealth shock } & \multicolumn{2}{|c|}{ capital shock } & \multicolumn{2}{|c|}{ T capital shock } & \multicolumn{2}{|c|}{ NT capital shock } \\
\hline & nominal & real & nominal & real & nominal & real & nominal & real \\
\hline GDP (fixed price) & - & - & + & + & + & + & + & + \\
\hline GDP (current price) & + & + & + & + & + & + & 0 & 0 \\
\hline consumption $(\mathrm{T})$ & + & + & + & + & + & + & 0 & 0 \\
\hline consumption $(\mathrm{N})$ & + & + & + & + & - & - & + & + \\
\hline production $(\mathrm{T})$ & - & - & + & + & + & + & 0 & 0 \\
\hline consumer spending & + & + & + & + & + & + & 0 & 0 \\
\hline investment $(\mathrm{T})$ & - & - & - & - & - & - & 0 & 0 \\
\hline investment (NT) & + & + & - & - & + & + & - & - \\
\hline rental rates $(\mathrm{T})$ & - & - & - & - & - & - & 0 & 0 \\
\hline rental rates $(\mathrm{N})$ & + & + & - & - & + & + & - & - \\
\hline wages & + & + & + & + & + & + & 0 & 0 \\
\hline relative price & + & + & + & + & + & + & - & - \\
\hline employment & - & - & + & + & + & + & 0 & 0 \\
\hline employment in $\mathrm{T}$ & - & - & + & + & + & + & 0 & 0 \\
\hline employment in $\mathrm{N}$ & + & + & - & - & - & - & 0 & 0 \\
\hline $\mathrm{K} / \mathrm{L}(\mathrm{T})$ & + & + & + & + & + & + & 0 & 0 \\
\hline $\mathrm{K} / \mathrm{L}(\mathrm{N})$ & - & - & + & + & + & + & + & + \\
\hline $\mathrm{K} / \mathrm{L}$ (aggregate) & + & + & + & + & + & + & + & + \\
\hline money & + & + & + & + & + & + & 0 & 0 \\
\hline bond holdings & + & + & - & - & - & - & 0 & 0 \\
\hline
\end{tabular}

Table 1: Signing impulse responses

The results for a common (proportional) capital shock are mostly similar, with three major exceptions: sectoral asymmetries, investment and household portfolios. Both sectors expand in terms of production. The excess capital in both sectors leads to a fall in rental rates, driving capital back towards its original level (investment drops in both sectors). There is an increase in total and traded employment. This second increase dominates the first, making employment shrink in nontradables. Finally, as households have higher income, they want to hold more money, which they achieve by decreasing their foreign bond holdings.

Relative to the common capital shock case, an increase in traded capital has major extra effect: it attracts labor to tradables, making nontradables more expensive. That calls for some initial investment into nontradables.

In case of an increase in nontraded capital, most effects are zero: the excess capital makes nontraded labor more productive, but that is fully compensated by a fall in nontradable prices, leaving nontradable employment unchanged. As nominal expenditures are unchanged, so is traded consumption. This implies that on impact, the nontraded sector is completely isolated from the rest of the economy: its excess capital stock gradually disappears, together with nontradable prices and rental rates recovering after an initial drop. 

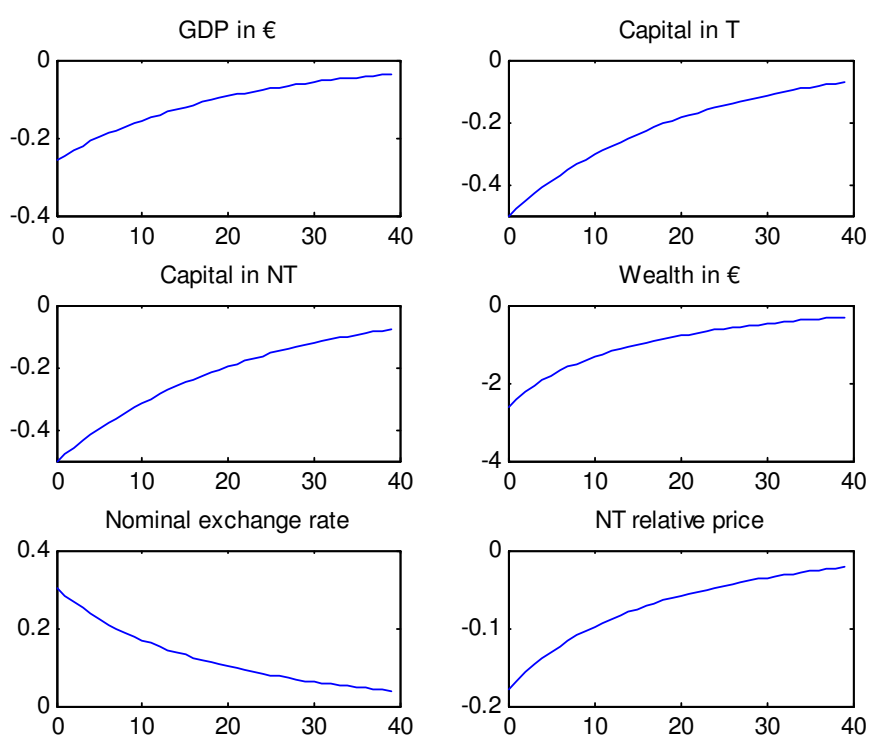

Figure 7: The real convergence process

\subsection{Real and nominal convergence paths}

Let us start with results corresponding to the real equilibrium path. Convergence implies an appreciating real exchange rate regardless of the relative intensities of the two sectors. If the nontraded sector is more labor-intensive, this real appreciation consists of both a nominal appreciation and an increase in the relative price of nontradables. If labor intensities are equal across sectors, then capital accumulation has no impact on the equilibrium relative price of nontradables; while if the nontraded sector is less labor-intensive, we observe a fall in the relative price of nontradables but an overall increase in their euro price level. ${ }^{20}$

Although capital is sector-specific, the role of relative capital intensities in determining the sign of the relative price effect indicates a Stolper-Samuelson mechanism: as long as capital is scarce, it has a high factor price. In the model with perfectly mobile capital, an increase in world interest rates increases the relative price of that sector which uses capital more intensively (inverse Stolper-Samuelson theorem). When the nontraded sector is more labor intensive, it means that the NT relative price starts from a low level, thus it must increase.

Figure 7 shows the evolution of GDP (in current euros), capital stocks, asset holdings, the nominal exchange rate and the nontraded relative price. As argued before, there is an increase of the relative price: under our choice of parameters, there is an $18 \%$ initial price gap due to

\footnotetext{
${ }^{20}$ These are all numerical results. If capital were fexible across sectors but gradual across borders, one could formally establish this relative price trichotomy.
} 
the low stock of capital. Since money is fixed, the required increase in real money holdings is implemented by a gradual strengthening of the nominal exchange rate (a total of 30\%). As the economy starts with a relatively low initial wealth level, it gradually accumulates assets. For higher initial wealth holdings, households would initially even decrease their asset holdings, and would start to save only after some periods. The same is true about foreign bond holdings (not reported).

Next we compare the results of the currency board case and the real equilibrium path. Both trajectories start from the same initial conditions for capital $\left(\hat{K}_{N}(0)\right.$ and $\left.\hat{K}_{T}(0)\right)$ and real wealth $\left(d a_{0}\right)$. Figures 8-11 depict the difference of the evolution of various variables under the two scenarios. The curves show the percentage difference of the currency board economy from the real path.

Interestingly, there are quite substantial differences between the two convergence processes. In general, the nominal economy is initially "overvalued" relative to the fexible case: relative prices are initially $2.5 \%$ higher, and production is leaned towards nontradables. This introduces a wedge between fixed (steady state) price and current (euro) price GDP: the former is higher in the fexible regime, while the latter is higher in the currency board. We also see that employment is tilted towards nontradables.

After around 5-10 periods, the currency board economy shifts to undervaluation, and it now features an asymmetry in favor of tradables. Thus the rate of return on tradable capital is initially lower under the currency board, and then it becomes higher. As shown by the evolution of Tobins q, the total effect is positive; the currency board economy accumulates traded and even aggregate capital faster than the fexible economy. Wealth accumulation, on the other hand, is faster in the fexible regime, and it also exhibits a higher share of money.

The general difference can be traced to an extra saving motif for consumers in a currency board, namely to build up their money stock. When we want to implement the real model within a fexible exchange rate framework, the required increase in money is achieved by an appreciating nominal exchange rate. Hence consumers can spend more, which then pushes resources (capital and labor) from tradables to nontradables. This is what we observe in later stages of convergence, when the currency board economy is already undervalued. The total effect on capital is ambiguous; in our numerical example, the real model exhibits slower capital accumulation. The effect on savings is even more complex: though currency board households do need to allocate more resources from their labor income to money holdings, fexible exchange rate households also have nonlabor income (the exchange rate gain) to save from, plus they face a higher overall return on money (the marginal utility plus the exchange rate gain). This second feature explains why they have a higher share of money in their portfolio. Finally, there are 

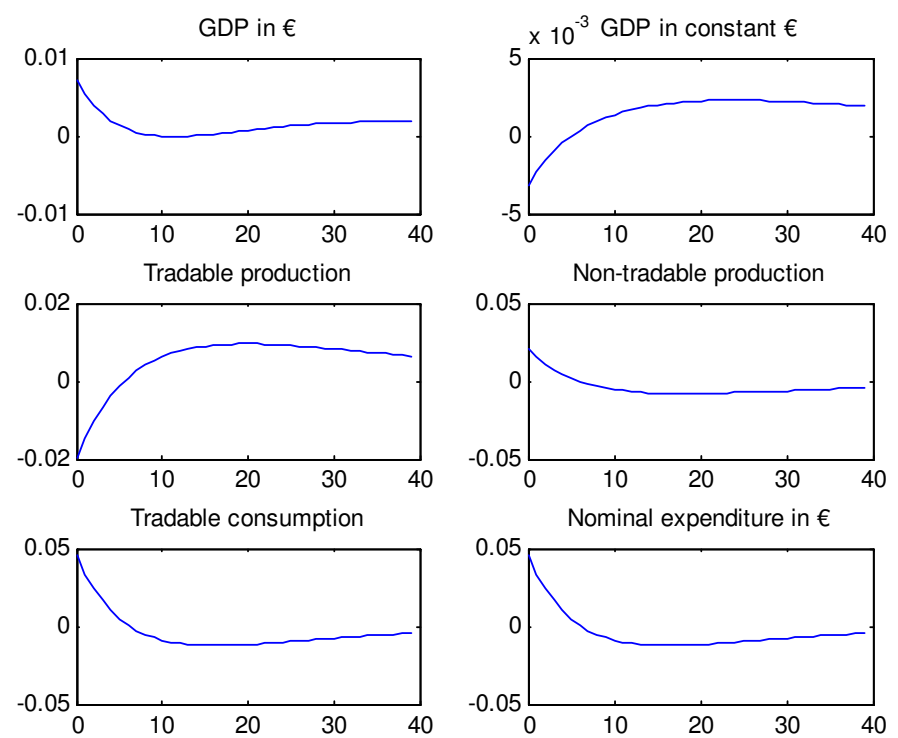

Figure 8: Difference between the nominal and the real model (1)
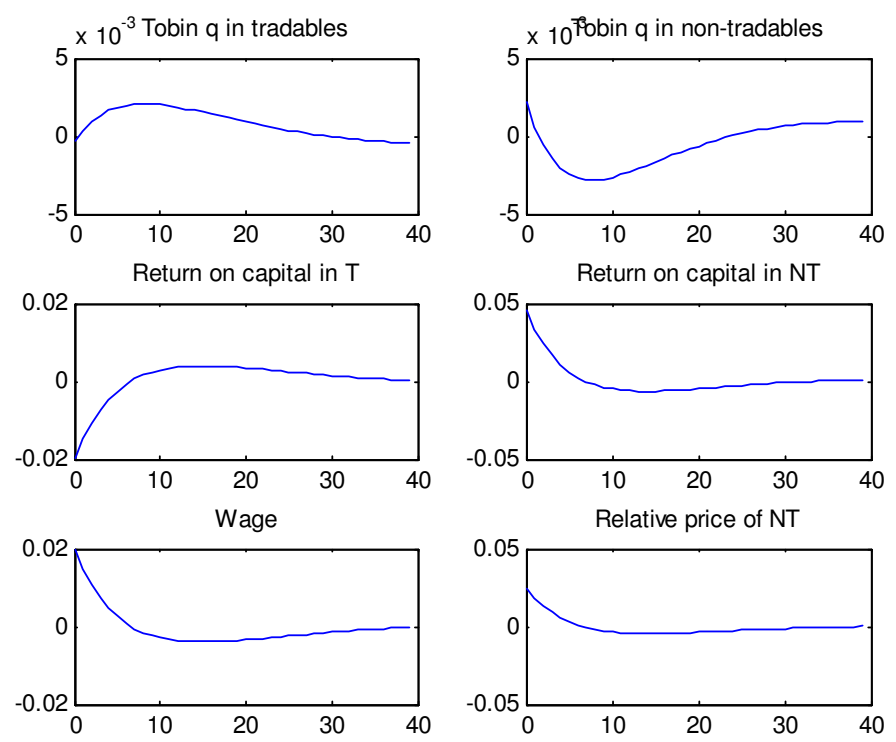

Figure 9: Difference between the nominal and the real model (2) 

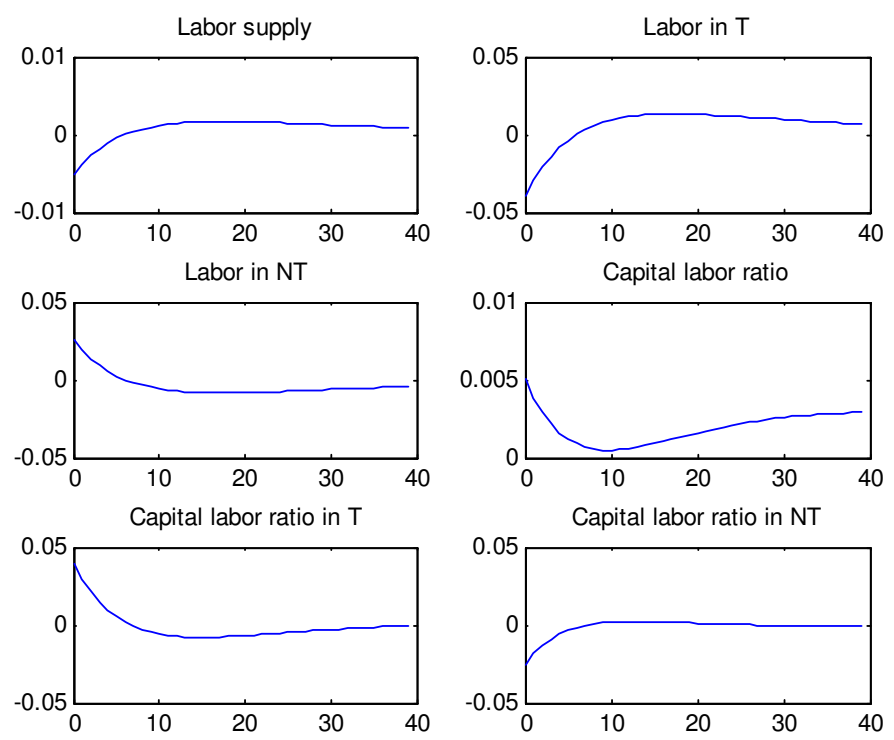

Figure 10: Difference between the nominal and the real model (3)
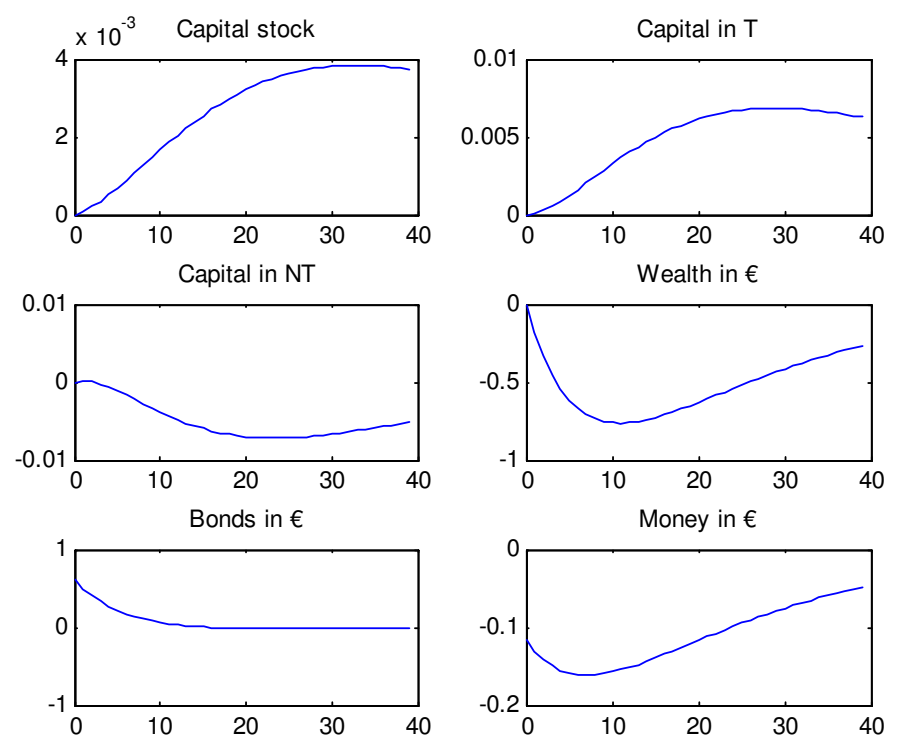

Figure 11: Difference between the nominal and the real model (4) 
also dynamic effects: lower capital and wealth stocks increase the savings and investment of the economy in the future.

Figures 12-15 compare two currency board economies, one having a 10\% weaker exchange rate. With the exception of wealth and bond holdings, all figures are percentage differences; while those two are absolute differences. For example, the relative price of nontradables moves by 0.008 , meaning that there is only a $92 \%$ paintbrush into nontradables. The more revalued economy is shifted towards nontradables, and it accumulates capital slower. In terms of GDP, if one looks at current price GDP, a revaluation increases output, while if one uses the steady state relative price $\bar{p}_{N}$, a revaluation reduces output. Not surprisingly, a revaluation decreases savings, since the windfall in wealth is gradually consumed. During this process, there is an increase in both money and foreign bond holdings. Overall, the figures show that there is a sizable and highly persistent real effect of the choice of the conversion rate.

\section{$7 \quad$ Some concluding comments}

This paper presents a simple theoretical model that addresses the growth process of a small trading economy with a traded and a nontraded sector. Besides presenting a fexible price, intertemporal optimization-based theory of equilibrium nominal and real exchange rates, the modelling framework is capable of addressing structural properties of a nominal growth process. The model also gives rise to a lasting real effect of nominal exchange rate shocks without price or wage setting frictions.

It is essentially a standard fexible price, two-sector (traded and nontraded), two-factor small open economy growth model with an endogenous risk premium, enriched with money-in-theutility. Overall, the model highlights that capital and financial wealth accumulation (real and nominal convergence) are deeply interconnected. Real exchange rate developments and capital accumulation have important two-sector, two-factor, open-economy determinants -in particular, adding a nominal asset holding motif like money-in-the-utility and q-theory to a standard twosector, two-factor open economy model with an endogenous risk premium is enough for short-run non-neutrality of money and the nominal exchange rate.

Another notable result is the comovement of investment and savings after a nominal exchange rate shock, even though investment is financed exclusively form the world capital market. The crucial step is that the nominal exchange rate influences traded prices, while money, bank deposits and bond holdings (more generally, fixed income financial instruments) are fixed in local currency. This means that if we measure everything in foreign currency, a nominal exchange rate shock is a pure wealth shock for consumers. In a sense, these assets can be viewed as an 

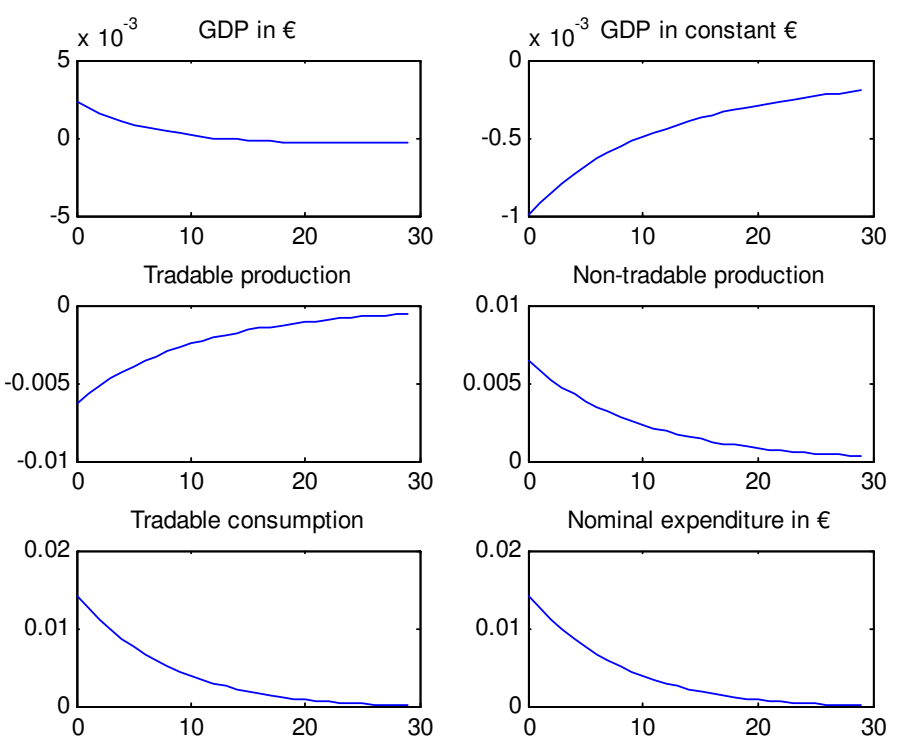

Figure 12: Real effects of a $10 \%$ stronger conversion rate (1)
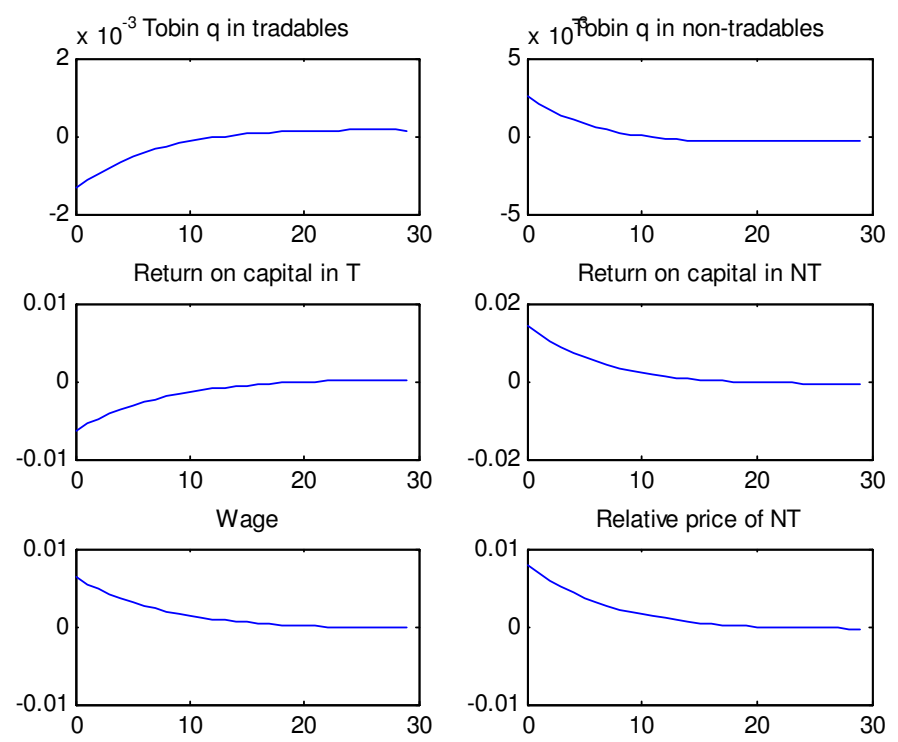

Figure 13: Real effects of a 10\% stronger conversion rate (2) 

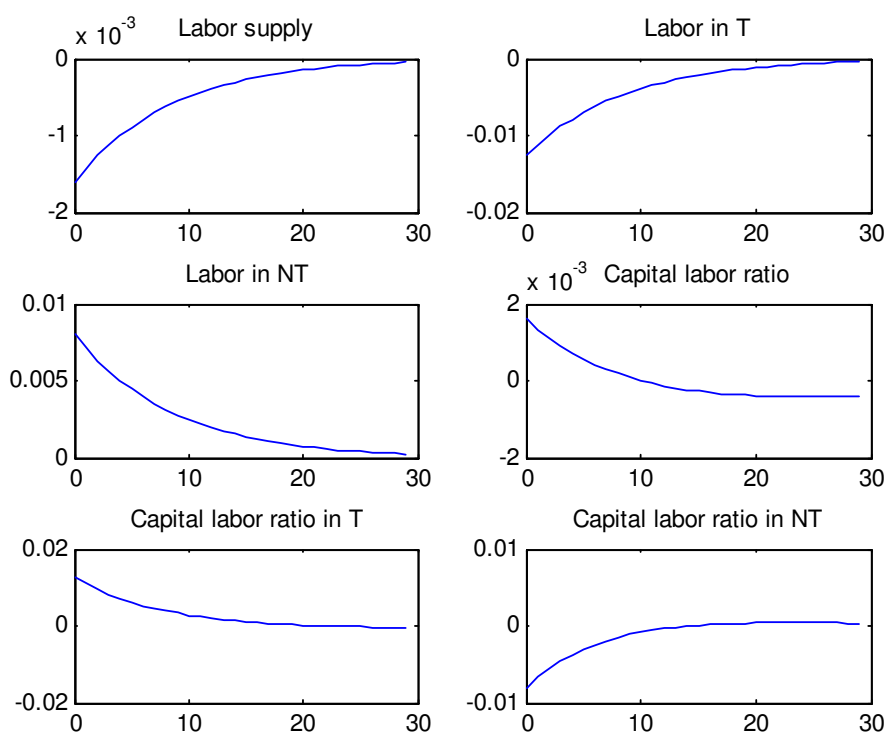

Figure 14: Real effects of a $10 \%$ stronger conversion rate (3)
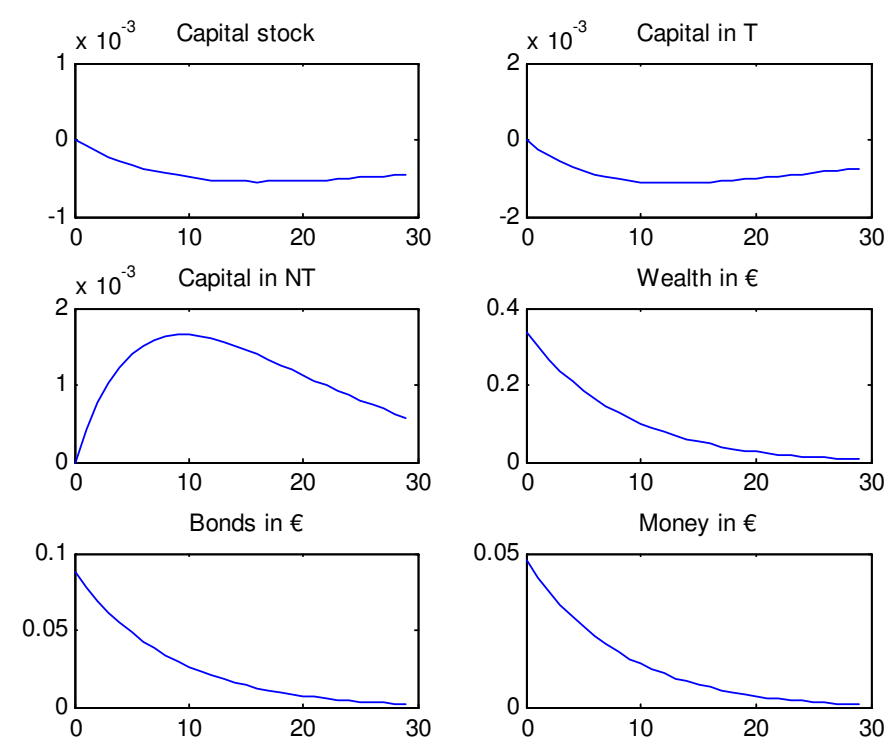

Figure 15: Real effects of a 10\% stronger conversion rate (4) 
"original nominal stickiness".

The results are particularly relevant for understanding the effects of nominal exchange rate movements, the impact of the exchange rate regime on the growth process, or the choice of the euro conversion rates for EMU candidates. The framework can also be utilized in assessing the price level implications of fiscal or income shocks. From a theory point of view, it also embeds a Balassa-Samuelson-type effect with a nominal side and gradual capital movements, thus a temporary role for demand. In particular, capital accumulation (FDI infbw) implies a real appreciation, endogenously divided between nominal appreciation and nontraded-traded relative prices changes.

Finally, our results show that a multisector model with nominal asset accumulation (like money-in-the-utility), endogenous risk premium and any real friction that makes the shortrun transformation curve nonlinear already implies short- and medium-run non-neutrality of monetary policy and nominal exchange rate shocks. Adding price or wage setting frictions would definitely increase the realism, fit and persistence of such a model, but one has to be careful in evaluating the role of price and wage setting in delivering the results.

\section{References}

[1] Aguiar, M. and G. Gopinath (2004): Emerging Market Business Cycles: The Cycle is the Trend, mimeo, University of Chicago, 2004.

[2] Balsam, A. and Z. Eckstein (2001): Real Business Cycles in a Small Open Economy with Non-Traded Goods, Working Paper 2001/3, Tel Aviv University.

[3] Benigno, P (2003): Optimal Monetary Policy in a Currency Area, Journal of International Economics, 2003.

[4] Bufman G. and L. Leiderman (1995): "Israels's Stabilization: Some Important Policy Lessons," in R. Dornbusch and S. Edwards (eds.), Reform, Recovery and Growth, Latin America and the Middle East, The University of Chicago Press, Chicago, 1995.

[5] Burstein, A., Eichenbaum, M., and S. Rebelo (2002): Why is Inflation so Low after Large Devaluations?, NBER Working Paper 8748, 2002.

[6] Christiano, L., M. Eichenbaum and Ch. Evans (2001): Nominal Rigidities and the Dynamic Effects of a Shock to Monetary Policy, NBER Working Paper 8403, 2001.

[7] Darvas, Zs. and A. Simon (2000): Potential Output and Foreign Trade in Small Open Economies, MNB Working Paper 2000/9. 
[8] Dornbusch. R. (1980): Open Economy Macroeconomics, Chapter 6, Basic Books. 1980.

[9] Dornbusch, R. and M. Mussa (1975): Consumption, Real Balances and the Hoarding Function, International Economic Review, 1975.

[10] Eichenbaum, M. and J. D. M. Fisher (2004): Evaluating the Calvo Model of Sticky Prices, NBER Working Paper 10617, 2004.

[11] Feldstein, M. and C. Horioka (1980): Domestic Savings and International Capital Flows, Economic Journal, 1980.

[12] Fiorito, R. and T. Kollintzas (1994): Stylized Facts of Business Cycles in the G7 from a Real Business Cycles Perspective, European Economic Review, 1994.

[13] Gourinchas, P. O. and H. Rey (2004): International Financial Adjustment, mimeo, Berkeley and Princeton.

[14] Harberger, A. C. (1962): The Incidence of the Corporation Income Tax, Journal of Political Economy, 1962.

[15] Hobijn, B., F. Ravenna and A. Tambalotti (2006): Menu Costs at Work: Restaurant Prices and the Introduction of the Euro, Quarterly Journal of Economics, forthcoming.

[16] Huffman, G. W. and M. A. Wynne (1999): The Role of Intratemporal Adjustment Costs in a Multisector Economy, Journal of Monetary Economics, 1999.

[17] Krugman. P. (1987): The Narrow Moving Band, the Dutch Disease, and the Competitive Consequences of Mrs. Thatcher: Notes on Trade in the Presence of Scale Dynamic Economies, Journal of Development Economics, 1987.

[18] Lane, P. and G. M. Milesi-Ferretti (2004): Financial Globalization and Exchange Rates, mimeo, Trinity College and IMF.

[19] Leamer, E.E. and J. Levinsohn (1995): International Trade Theory: The Evidence, in Handbook of International Economics III, Elsevier, 1995.

[20] Lucas, R. E, Jr. (1988): On the Mechanics of Economic Development, Journal of Monetary Economics, 1988

[21] Obstfeld, M. and K. Rogoff (1996): Foundations of International Macroeconomics, The MIT Press, 1996.

[22] Rebelo, S. (1991): Long-Run Policy Analysis and Long-Run Growth, Journal of Political Economy, 1991. 
[23] Rebelo, S. and C. A. Végh (1995): Real Effects of Exchange-Rate Based Stabilization: An Analysis of Competing Theories, in NBER Macroeconomics Annual, 1995.

[24] Schmitt-Grohé, S. and M. Uribe (2003): Closing Small Open Economy Models, Journal of International Economics, 2003..

[25] Taylor, J. (1980): Aggregate Dynamics and Staggered Contracts, Journal of Political Economy, 1980.

[26] Tille, C. (2005): Financial Integration and the Wealth Effect of Exchange Rate Fluctuations, mimeo, Federal Reserve Bank of New York.

[27] Ventura, J. (1997): Growth and Interdependence, Quarterly Journal of Economics, 1997.

[28] Woodford, M. (2003): Interest and Prices: Foundations of a Theory of Monetary Policy, Princeton University Press, 2003.

\section{Appendix}

\section{A The Hungarian episode}

To illustrate a specific example to the symptoms of a wealth shock ("overvaluation"), we present some recent evidence from Hungary. Looking at Hungarian data between 1999-2003, we find the following: ${ }^{21}$ (1) a drop in real corporate investment around 1999, and a flattening of the total investment to GDP ratio (Panels A and B of Figure 7); (2) a strong increase in the consumption to GDP ratio since 2000 (Panel B); (3) a strong comovement of corporate investment and the stock market index -the 1999 episode is mixed here with the Russian crisis, but from 2000, the U-shaped pattern of investment and the stock market is common (Panel C); (4) massive real wage growth episodes around 1999, 2000, partly driven by public sector wages (Panel D); (5) a general increase in the nontraded-traded relative price, with historical highs since 2000-2001 (Panel E); (6) a shift of (total) investment from industry towards services and real estate (Panel $\mathrm{F}) ;^{22}(7)$ a tilt of employment towards the service sector (Panel G); (8) and an overall high current account deficit, particularly deteriorating since 1998, with a temporary reversal in 2001 and $2002($ Panel H).

\footnotetext{
${ }^{21}$ There was no apparent extra GDP growth - but the fact that there was no slowdown among the international stagnation of the 2000s can be interpreted in such a way. By 2003, GDP growth indeed declined.

${ }^{22}$ This change in total investment shares is mostly driven by a constant industry share within corporate investment, and an overall increase in public investment (dominantly services) and household investment (dominantly real estate).
} 


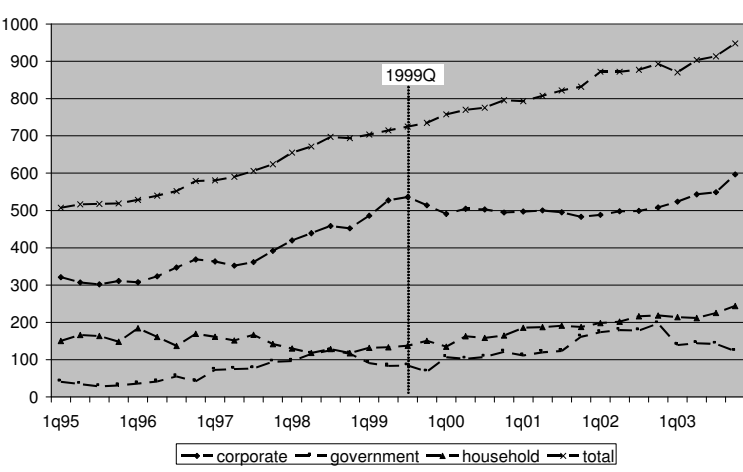

Panel A: Investment (real)

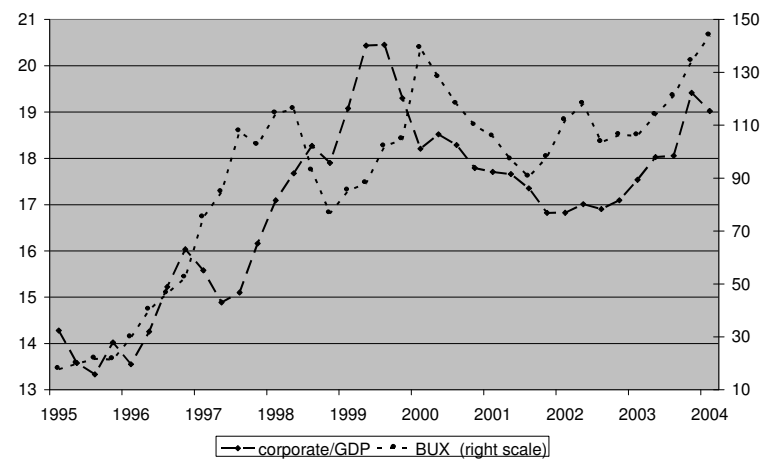

Panel C: Investment and the stock index

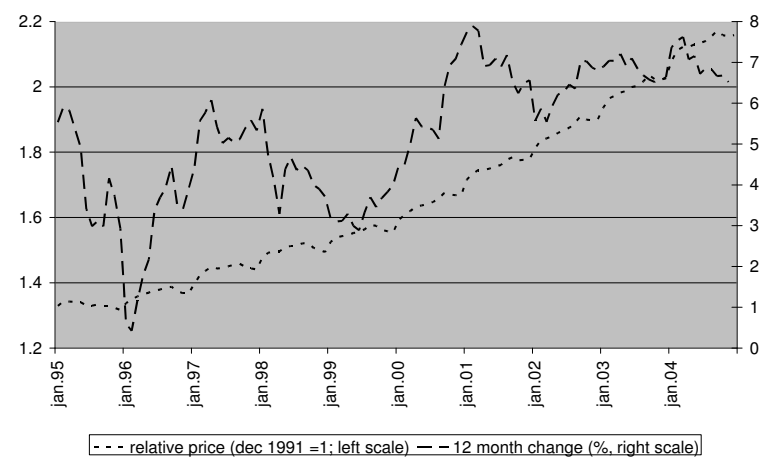

Panel E: The nontraded-traded relative price

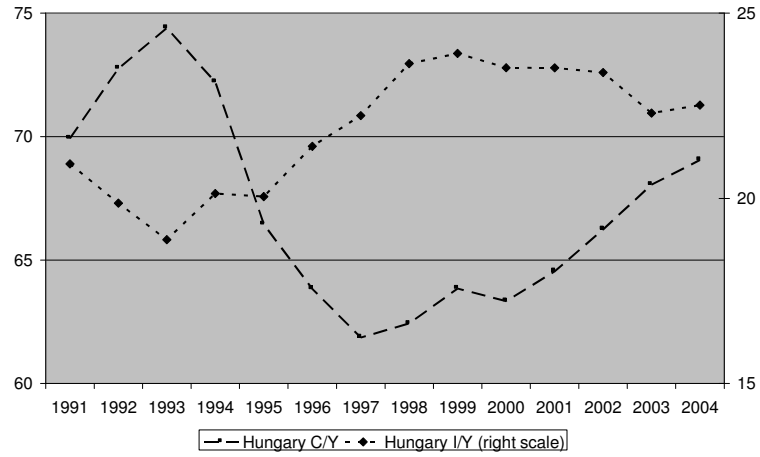

Panel B: Investment and consumption ratios

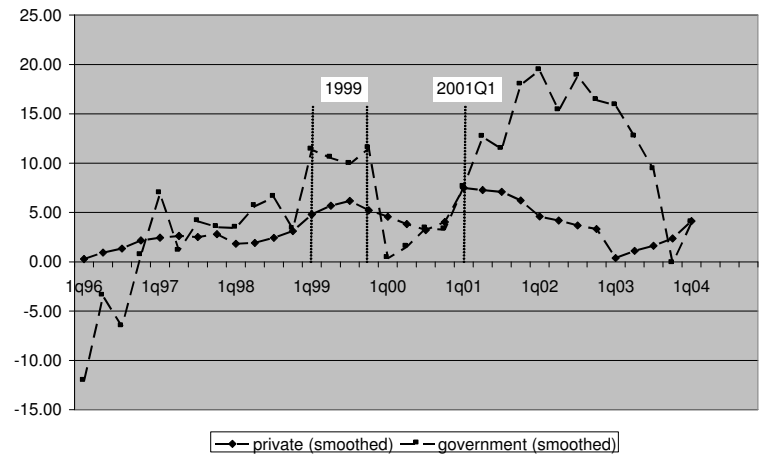

Panel D: Real wages

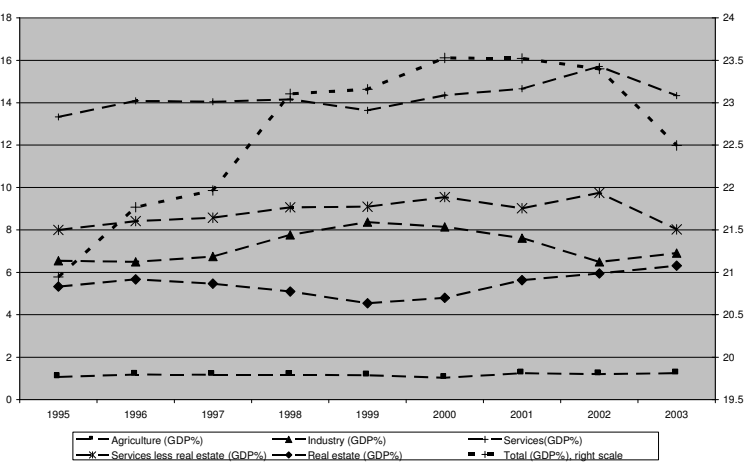

Panel F: Investment by sectors 


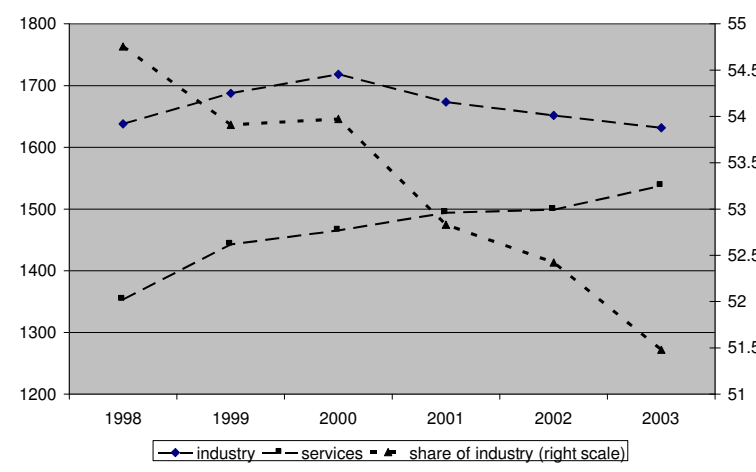

Panel G: Employment in the private sector

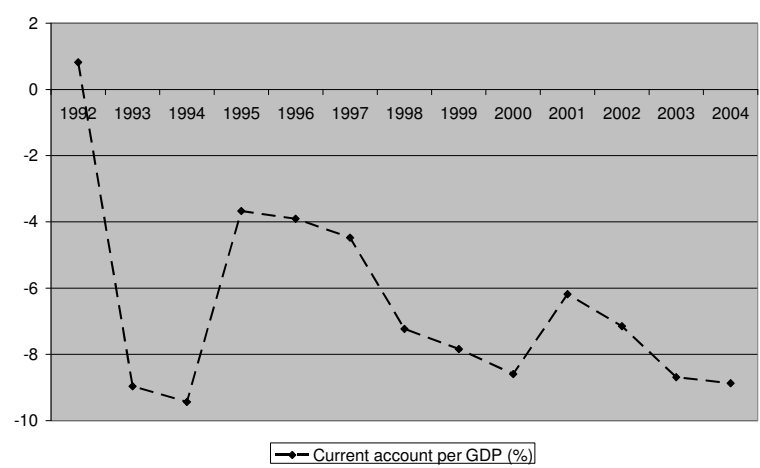

Panel H: The current account

Figure 16: Hungary in the late nineties

The policy environment can be summarized as (1) a correction in the public versus private sector wage ratio, around the beginning of 1999; (2) a large increase in minimum wage legislation, around the beginning of 2001; (3) investment subsidies to SMEs and (4) subsidized real estate loans, from around 1999; (5) a large nominal appreciation (monetary restriction), in the form of widening the exchange rate band in May 2001, (6) followed by a massive fiscal expansion, partly in the form of public sector wage increases (end of 2002). The exact timing of this latter fiscal expansion is somewhat unclear: the rise in public sector wages unambiguously came after the monetary contraction, but the fiscal stance before and after the monetary developments is subject to heated political debates in Hungary.

\section{B Loglinearization}

First we express all within-period variables $\left(\hat{r}_{N}, \hat{r}_{T}, \hat{k}_{N}, \hat{k}_{T}, \hat{w}, \hat{p}_{N}, \hat{L}, \hat{l}_{N}\right.$ and $\left.\hat{h}\right)$ as functions of the state and co-state variables $\left(\hat{K}_{T}, \hat{K}_{N}, \hat{q}_{T}, \hat{q}_{N}, \hat{x}\right.$ and $\left.d a\right)$.From firm-level profit maximization (9)-(11):

$$
\begin{aligned}
r_{T}=(1-\beta) k_{T}^{-\beta} & \Longrightarrow \hat{r}_{T}=-\beta \hat{k}_{T} \\
w=\beta k_{T}^{1-\beta} & \Longrightarrow \hat{w}=(1-\beta) \hat{k}_{T} \\
r_{N}=(1-\alpha) p_{N} k_{N}^{-\alpha} & \Longrightarrow \hat{r}_{N}=\hat{p}_{N}-\alpha \hat{k}_{N} \\
w=\alpha p_{N} k_{N}^{1-\alpha} & \Longrightarrow \hat{w}=\hat{p}_{N}+(1-\alpha) \hat{k}_{N} .
\end{aligned}
$$


Express everything in terms of $\hat{k}_{N}$ and $\hat{k}_{T}$ :

$$
\begin{aligned}
\hat{r}_{T} & =-\beta \hat{k}_{T} \\
\hat{w} & =(1-\beta) \hat{k}_{T} \\
\hat{p}_{N} & =(1-\beta) \hat{k}_{T}-(1-\alpha) \hat{k}_{N} \\
\hat{r}_{N} & =(1-\beta) \hat{k}_{T}-\hat{k}_{N} .
\end{aligned}
$$

Loglinearizing (6):

$$
\begin{aligned}
\omega L^{\phi} & =\frac{w}{x} \\
\hat{L} & =-\frac{1}{\phi} \hat{x}+\frac{1}{\phi} \hat{w} .
\end{aligned}
$$

Loglinarizing the definition of capital-labor ratios:

$$
\begin{aligned}
k_{N} & =K_{N} /\left(l_{N} L\right) \\
\hat{k}_{N} & =\hat{K}_{N}-\hat{l}_{N}-\hat{L} \\
k_{T} & =K_{T} /\left(\left(1-l_{N}\right) L\right) \\
\hat{k}_{T} & =\hat{K}_{T}-\hat{L}+\underbrace{\frac{\bar{l}_{N}}{1-\bar{l}_{N}}}_{\sigma} \hat{l}_{N} .
\end{aligned}
$$

Loglinearize the definition of $x$ :

$$
\hat{x}=\hat{c}+(1-\lambda) \hat{p}_{N} .
$$

Using the definition of $c$ and the consumption optimality condition (2), we get

$$
\begin{aligned}
c & =c_{T}^{\lambda} c_{N T}^{1-\lambda}=\left(\frac{\lambda}{1-\lambda}\right)^{\lambda} p_{N}^{\lambda} c_{N T} \\
\hat{x} & =\hat{p}_{N}+\hat{c}_{N T} .
\end{aligned}
$$

From market clearing in nontraded goods:

$$
\begin{aligned}
c_{N T} & =l_{N} L k_{N T}^{1-\alpha} \\
\hat{c}_{N T} & =\hat{l}_{N}+\hat{L}+(1-\alpha) \hat{k}_{N},
\end{aligned}
$$

so

$$
\hat{x}=\hat{p}_{N}+\alpha \hat{l}_{N}+\alpha \hat{L}+(1-\alpha) \hat{K}_{N} .
$$


Equations (28)-(31),(32),(33),(34) and (35) are a system of eight linear equations for eight unknown variables: $\hat{r}_{N}, \hat{r}_{T}, \hat{k}_{N}, \hat{k}_{T}, \hat{w}, \hat{p}_{N}, \hat{L}$ and $\hat{l}_{N}$.

We need to obtain $\sigma=\frac{\bar{l}_{N}}{1-\bar{l}_{N}}$, the steady state ratio of sectoral employment. Using steady state conditions:

$$
\begin{aligned}
\bar{k}_{T} & =\left(\frac{1-\beta}{\rho}\right)^{1 / \beta} \\
\bar{k}_{N T} & =\bar{k}_{T} \frac{1-\alpha}{\alpha} \frac{\beta}{1-\beta} \\
\bar{p}_{N} & =\frac{\beta}{\alpha}\left(\frac{1-\alpha}{\alpha} \frac{\beta}{1-\beta}\right)^{\alpha-1}\left(\frac{1-\beta}{\rho}\right)^{\frac{\alpha-\beta}{\beta}} \\
\bar{c} & =\left(\frac{\lambda}{1-\lambda}\right)^{\lambda} \bar{p}_{N}^{\lambda} \bar{L} \bar{l}_{N} \bar{k}_{N T}^{1-\alpha} \\
\bar{w} & =\beta \bar{k}_{T}^{1-\beta}=\chi \bar{p}_{N}^{1-\lambda} \bar{c} / \bar{L}-\rho \bar{b} / \bar{L} .
\end{aligned}
$$

Plugging everything into this last expression yields

$$
\bar{l}_{N}=\alpha(1-\lambda)+\frac{\alpha(1-\lambda) \bar{b}}{\bar{L}\left(\frac{1-\beta}{\rho}\right)^{\frac{1-\beta}{\beta}}} .
$$

To obtain $\hat{h}$, loglinearize $(5)$ :

$$
\begin{aligned}
\frac{(1+\rho) \gamma}{h_{t}} & =\frac{1+\rho}{x_{t}}-E_{t} \frac{\varepsilon_{t}}{\varepsilon_{t+1}} \frac{1}{x_{t+1}} \\
\rho \hat{h}_{t} & =(1+\rho) \hat{x}_{t}+E_{t}\left[e_{t}-e_{t+1}-\hat{x}_{t+1}\right]=(1+\rho) \hat{x}_{t}-E_{t}\left[e_{t}-e_{t+1}\right]-\hat{x}_{t}-\frac{\rho}{1+\rho} \hat{\imath}_{t} \\
& =\rho \hat{x}+e_{t}-E_{t} e_{t+1}+\frac{\psi}{1+\rho}(d a-\bar{h} \hat{h}) \\
\hat{h} & =\frac{\rho(1+\rho)}{\rho(1+\rho)+\psi \bar{h}} \hat{x}+\frac{\psi}{\rho(1+\rho)+\psi \bar{h}} d a+\frac{e_{t}-E_{t} e_{t+1}}{(1+\rho)+\psi \bar{h}} .
\end{aligned}
$$

We now turn to the dynamic equations. Capital accumulation and the evolution of Tobins $q$ are driven by

$$
\begin{aligned}
K_{X}(t) & =\left(1+\frac{q_{X}(t)-1}{\delta_{X}}\right) K_{X}(t-1) \Longrightarrow \hat{K}_{X}(t)=\hat{K}_{X}(t-1)+\hat{q}_{X} \frac{1}{\delta_{X}} \\
(1+\rho) q_{X}(t) & =E_{t}\left(q_{X}(t+1)+r_{X}(t+1)+\frac{\left(q_{X}(t+1)-1\right)^{2}}{2 \delta_{X}}\right) \\
(1+\rho) \hat{q}_{X}(t) & =E_{t} \hat{q}_{X}(t+1)+\rho E_{t} r_{X}(t+1) .
\end{aligned}
$$


Since the stance of fiscal policy is described by $\tau=0$, wealth accumulation is governed by

$$
a_{t}=w_{t} L_{t}-x_{t}+\frac{\varepsilon_{t-1}}{\varepsilon_{t}} h_{t-1}+\left(1+\rho+d\left(a_{t-1}-h_{t-1}\right)\right)\left(a_{t-1}-h_{t-1}\right) .
$$

Then we can loglinearize the wealth accumulation equation:

$$
\begin{aligned}
a_{t}= & \frac{w}{\bar{w}} \bar{w} \frac{L}{\bar{L}} \bar{L}-\bar{x} \frac{x}{\bar{x}}+\frac{h_{t-1}}{\bar{h}} \frac{\varepsilon_{t-1}}{\varepsilon_{t}} \bar{h}+\left(1+\rho+d\left(b_{t-1}\right)\right)\left(d a_{t-1}+\bar{a}-\hat{h}_{t-1} \bar{h}-\bar{h}\right) \\
= & \hat{w} \bar{w} \bar{L}+\hat{L} \bar{w} \bar{L}-\bar{x} \hat{x}++\bar{h} \hat{h}_{t-1}+\bar{h} e_{t-1}-\bar{h} e_{t}+\left[d\left(b_{t-1}\right)\right]\left(d a_{t-1}+\bar{a}-\hat{h}_{t-1} \bar{h}-\bar{h}\right) \\
& +(1+\rho)\left(d a_{t-1}-\hat{h}_{t-1} \bar{h}\right) .
\end{aligned}
$$

Since $d(a-h)=\psi\left(e^{-(b-\bar{b})}-1\right)$, we have

$$
d a_{t}=\bar{w} \bar{L} \hat{w}_{t}+\bar{w} \bar{L} \hat{L}_{t}-\bar{x} \hat{x}_{t}+\bar{h} e_{t-1}-\bar{h} e_{t}-\psi \bar{b}\left(d a_{t-1}-\bar{h} \hat{h}_{t-1}\right)+(1+\rho) d a_{t-1}-\rho \bar{h} \hat{h}_{t-1} .
$$

The expression for $\frac{d}{d t} \hat{x}$ (nominal expenditures in euros) is obtained by loglinearizing (17):

$$
\begin{aligned}
\frac{1+\rho}{x_{t}} & =\left(1+\rho+d\left(a_{t}-h_{t}\right)\right) E_{t} \frac{1}{x_{t+1}} \\
\hat{x}_{t} & =E_{t} \hat{x}_{t+1}+\frac{\psi}{1+\rho}\left(d a_{t}-\bar{h} \hat{h}_{t}\right) .
\end{aligned}
$$

The stability of the system is determined by the signs of (the real part of its) eigenvalues, while general solutions can be obtained as linear combinations of its eigenvectors. Given that the investment and consumption optimization problem is also subject to a transversality condition, three initial conditions (on $K_{T}, K_{N}$ and $h$ ) pin down the system. This means that we must have three stable (with a positive real part) and three unstable eigenvalues.

Turning to the real model, the loglinearization of $\hat{q}_{X}$ and $\hat{k}_{X}$ remains unchanged. Loglinearizing (23):

$$
\hat{x}_{t}=E_{t} \hat{x}_{t+1}+\frac{\psi}{1+\rho} d b_{t}
$$

while from (22),

$$
\begin{aligned}
b_{t} & =w_{t} L_{t}-x_{t}+\left(1+\rho+d\left(b_{t-1}\right)\right) b_{t-1} \\
d b_{t} & =\bar{w} \bar{L} \hat{w}_{t}+\bar{w} \bar{L} \hat{L}_{t}-\bar{x} \hat{x}_{t}-\psi \bar{b} d b_{t-1}+(1+\rho) d b_{t-1}
\end{aligned}
$$

We can also calculate two measures of real GDP in both models. The first is current GDP in euros -i.e., measured in tradables: $y=y_{T}+p_{N} y_{N}$, while the second is GDP in fixed (steady 
state) prices: $y^{f i x}=y_{T}+\bar{p}_{N} y_{N}$. Loglinearizing the first yields

$$
\begin{aligned}
y= & y_{T}+p_{N} y_{N}=\left(1-l_{N}\right) l k_{T}+p_{N} l l_{N} k_{N} \\
(1+\hat{y}) \bar{y}= & \left(1-\bar{l}_{N}\left(1+\hat{l}_{N}\right)\right)(1+\hat{l}) \bar{l}\left(1+\hat{k}_{T}\right) \bar{k}_{T} \\
& +\bar{p}_{N}\left(1+\hat{p}_{N}\right) \bar{l}_{N}\left(1+\hat{l}_{N}\right) \bar{l}(1+\hat{l}) \bar{k}_{N}\left(1+\hat{k}_{N}\right) \\
\hat{y}= & \frac{\bar{y}_{T}}{\bar{y}}\left(\hat{l}+\hat{k}_{T}\right)-\frac{\bar{l}_{N} \bar{l}_{T}}{\bar{y}} \hat{l}_{N}+\frac{\bar{y}_{N}}{\bar{y}}\left(\hat{p}_{N}+\hat{l}+\hat{l}_{N}+\hat{k}_{N}\right) \\
= & \hat{l}+\hat{k}_{T}+\frac{\bar{y}_{N}}{\bar{y}} \hat{p}_{N}+\left(\frac{\bar{y}_{N}}{\bar{y}}-\sigma \frac{\bar{y}_{T}}{\bar{y}}\right) \hat{l}_{N} ;
\end{aligned}
$$

while the second differs only slightly:

$$
\begin{aligned}
& y=y_{T}+\bar{p}_{N} y_{N} \\
& \hat{y}=\frac{\bar{y}_{T}}{\bar{y}}\left(\hat{l}+\hat{k}_{T}\right)-\frac{\bar{l}_{N} \bar{l}_{T}}{\bar{y}} \hat{l}_{N}+\frac{\bar{y}_{N}}{\bar{y}}\left(\hat{l}+\hat{l}_{N}+\hat{k}_{N}\right)=\hat{l}+\hat{k}_{T}+\left(\frac{\bar{y}_{N}}{\bar{y}}-\sigma \frac{\bar{y}_{T}}{\bar{y}}\right) \hat{l}_{N} .
\end{aligned}
$$




\section{Discussion Papers published since 1999}

\section{4}

Gergely CSORBA: Screening Contracts in the Presence of Positive Net-work Effects MT-DP. 2004/14

K. BOGNÁR - L. SMITH: We Can’t Argue Forever MT-DP. 2004/15

JUHÁSZ A. - SERES A. - STAUDER M.: A kereskedelmi koncentráció módszertana MTDP. 2004/16

Júlia LENDVAI: Inflation Inertia and Monetary Policy Shocks MT-DP. 2004/17

A. FREDERIKSEN -E. TAKÁTS: Optimal Incentive Mix of Performance Pay and Efficiency Wage MT-DP. 2004/18

Péter KONDOR: The More We Know, the Less We Agree: Public Announcements and Higher-Order Expectations. MT-DP. 2004/19

BARANYI B. -BALCSÓK I.: Határmenti együttmúködés és a foglalkoztatás - keletmagyarországi helyzetkép. MT-DP. 2004/20

L.Á. KÓCZY - L. LAUWERS: The Minimal Dominant Set is a Non-Empty Core-Extension. MT-DP. 2004/21

Miklós KOREN: The Law of Two Prices: Trade Costs and Relative Price Variability MT-DP. 2004/22

A. AMBRUS - R. ARGENZIANO: Network Markets and Consumer Coordination. MT-DP. 2004/23

LÓCSEI Hajnalka: A vidéki városi agglomerációk fejlődési pályája. MT-DP. 2004/24

J.D.BROWN - J.S. EARLE - Á. TELEGDY: Does Privatization Raise Productivity?. MT-DP. 2004/25

HÁRS Ágnes: A magyar munkaerő-migráció regionális sajátosságairól MT-DP. 2004/26

2005

GÁCS János: A lisszaboni folyamat: rejtélyek, elméleti problémák és gyakorlati nehézségek. MT-DP. 2005/1

PÉTERI Gábor: Igazodás a piacgazdaság szabályaihoz és megfelelés a helyi elvárásoknak - A városi polgármesterek értékrendje, 2004. MT-DP. 2005/2

SZALAI Ákos: Adóverseny az iparűzési adóban - Az 5000 fő fölötti települések adópolitikája a 2000-es években. MT-DP. 2005/3

Gábor BÉKÉS - Balázs MURAKÖZY: Firm Behaviour and Public Infrastructure: The Case of Hungary. MT-DP. 2005/4

Gusztav NEMES: The Politics of Rural Development in Europe. MT-DP. 2005/5

Gusztav NEMES: Integrated Rural Development - the Concept and Its Operation. MT-DP. 2005/6

JUHÁSZ Anikó -SERES Antal -STAUDER Márta: A kereskedelmi koncentráció tendenciái MT-DP. 2005/7

Hajnalka TARJÁNI: Estimating some Labour Market Implications of Skill Biased Technology Change and imports in Hungary. MT-DP. 2005/8

L. HALPERN - M.KOREN.- Á. SZEIDL: Import and Productivity. MT-DP. 2005/9

Szabolcs LŐRINCZ: Persistence Effects in a Dynamic Discrete Choice Model - Application to Low-End Computer Servers. MT-DP. 2005/10

Péter VIDA: A Detail-free Mediator and the 3 Player Case. MT-DP. 2005/11

László Á. KÓCZY: The Core Can Be Accessed with a Bounded Number of Blocks. MT-DP. 2005/12 
Viktória KOCSIS: Network Asymmetries and Access Pricing in Cellular Telecommunications. MT-DP. 2005/13

István KÓNYA: Economic Development, Exchange Rates, and the Structure of Trade. MTDP. $2005 / 14$

Gábor G. SZABÓ - Krisztina BÁRDOS: Vertical Coordination by Contracts in Agribusiness: An Empirical Research in the Hungarian Dairy Sector MT-DP. 2005/15

Attila AMBRUS: Theories of Coalitional Rationality. MT-DP. 2005/16

Jin-Chuan DUAN - András FÜLÖP: Estimating the Structural Credit Risk Model When

Equity Prices Are Contaminated by Trading Noises. MT-DP. 2005/17

Lawrence UREN - Gábor VIRÁG: Wage Inequality in a Burdett-Mortensen World. MT-DP. 2005/18

Berthold HERRENDORF - Ákos VALENTINYI: Which Sectors Make the Poor Countries so Unproductive? MT-DP. 2005/19

János GÁCS: The Macroeconomic Conditions of EU-inspired Employment Policies. MT-DP. 2005/20

CSATÓ Katalin: Egy fiziokrata: Paul-Pierre Le Mercier de la Rivière. MT-DP. 2005/21

2006

Krisztina MOLNÁR - Sergio SANTORO: Optimal Monetary Policy When Agents Are

Learning. MT-DP. 2006/1

András SIMONOVITS: Social Security Reform in the US: Lessons from Hungary. MT-DP. 2006/2

Iván MAJOR - Why do (or do not) banks share customer information?. A comparison of mature private credit markets and markets in transition. MT-DP. 2006/3

Mária LACKÓ: Tax Rates with Corruption: Labour-market Effects. Empirical Cross-country Comparisons on OECD Countries. MT-DP. 2006/4

György MOLNÁR - Zsuzsa KAPITÁNY: Mobility, Uncertainty and Subjective Well-being in Hungary. MT-DP. 2006/5

Rozália PÁL - Roman KOZHAN: Firms' investment under financing constraints. A euro area investigation. MT-DP. 2006/6

Anna IARA: Skill diffusion by temporary migration? Returns to Western European working experience in the EU accession countries. MT-DP. 2006/7

György MOLNÁR - Zsuzsa KAPITÁNY: Uncertainty and the Demand for Redistribution. MT - DP. 2006/8

Discussion Papers are available at the website of Institute of Economics Hungarian Academy of Sciences: http://econ.core.hu 